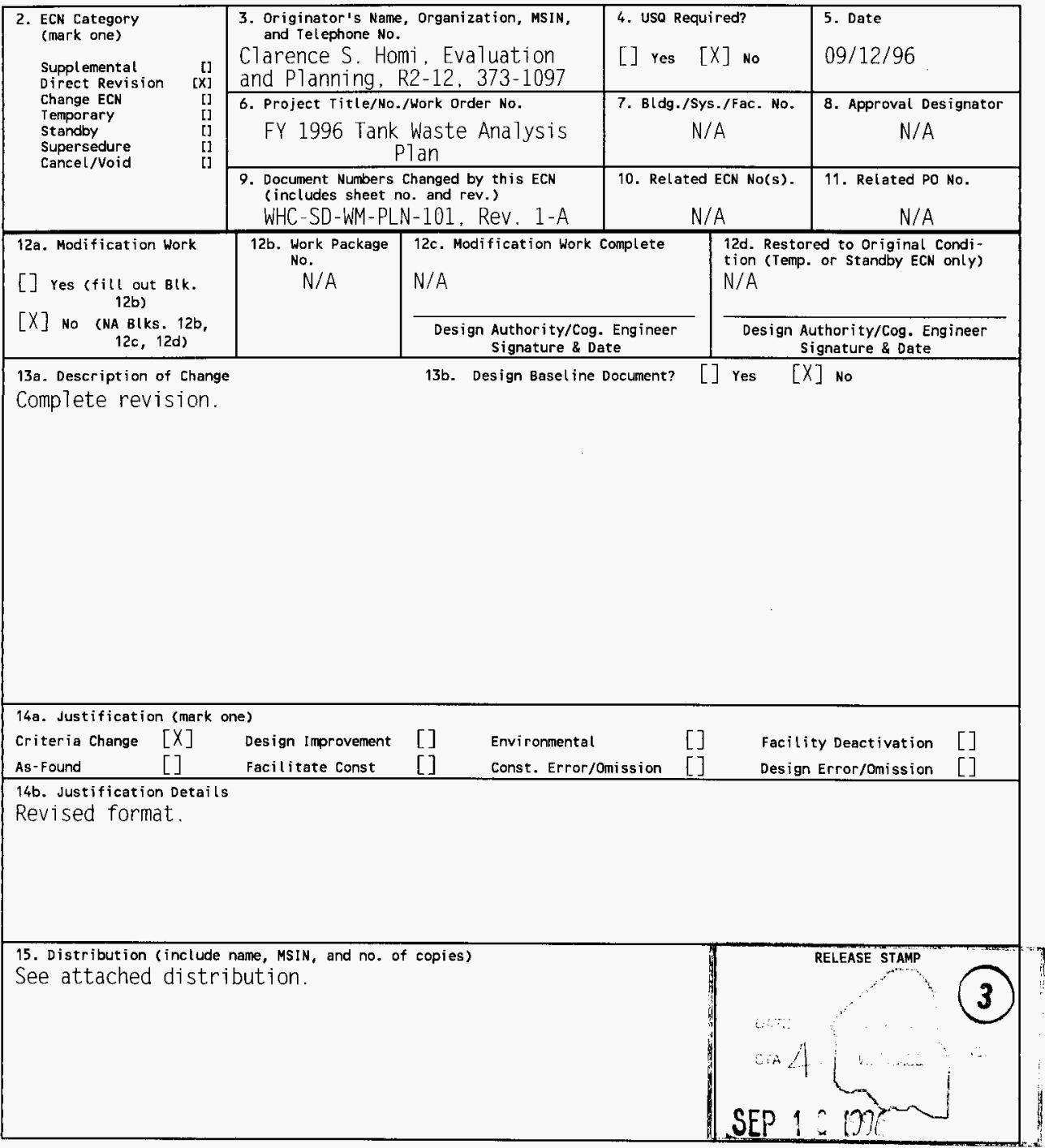

A-7900-013-2(05/96) GEF095 


\section{ENGINEERING CHANGE NOTICE}

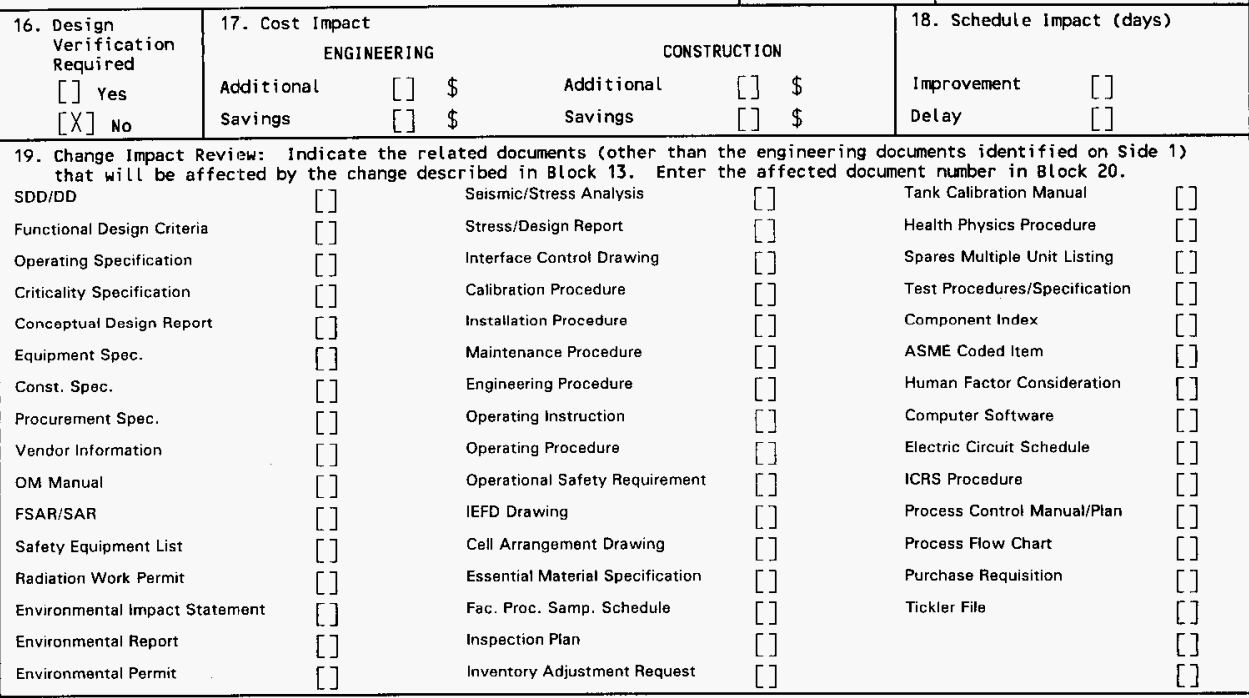

20. Other Affected Documents: (NOTE: Documents Listed below will not be revised by this ECN.) Signatures below indicate that the signing organization has been notified of other affected documents listed below. Document Number/Revision Document Number/Revision Document Number Revision $N / A$

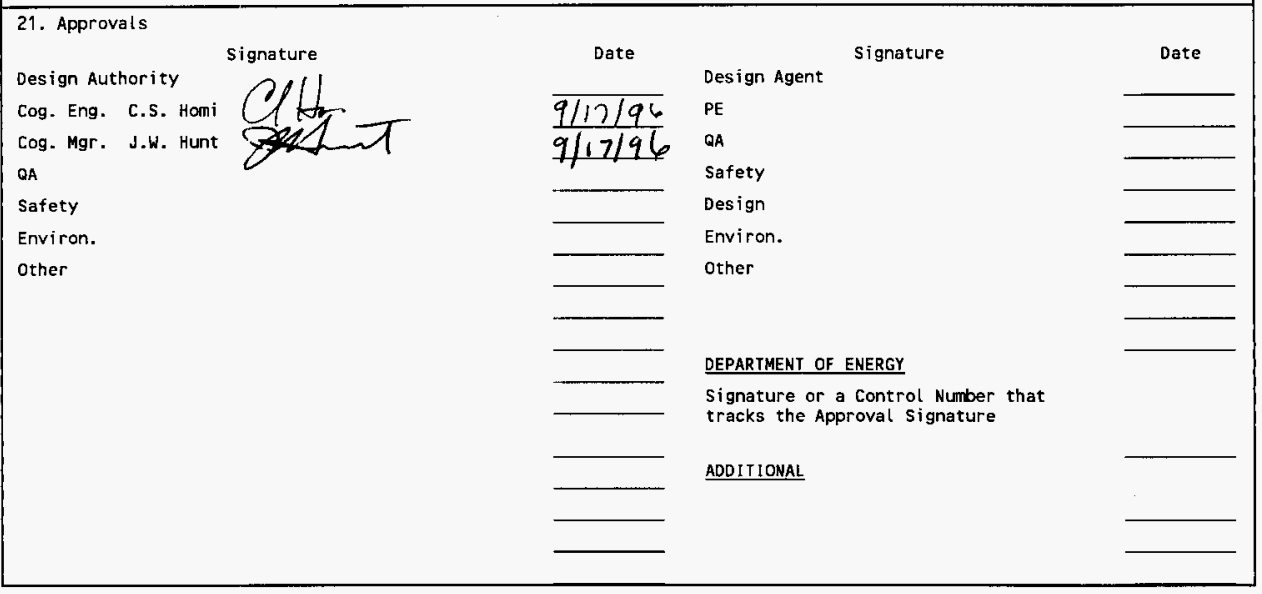




\title{
FY 1996 Tank Waste Analysis Plan
}

\author{
Clarence S. Homi
}

Westinghouse Hanford Company, Richland. WA 99352

U.S. Department of Energy Contract DE-AC06-87RL10930

$\begin{array}{lll}\text { EDT/ECN: } & \text { ECN }-635349 & \text { UC: } 2070 \\ \text { Org Code: } & 79200 & \text { Charge Code: N4G6A } \\ \text { B\&R Code: } & \text { EW } 3120074 & \text { Tota7 Pages: } 46\end{array}$

Key Words: FY 1996. TWAP, Tank Waste Analysis Plan, Plan

Abstract: N/A

TRADEMARK DISCLAIMER. Reference herein to any specific comercial product, process, or service by trade name, trademark, manufacturer, or otherwise, does not necessarily constitute or imply its endorsement, recommendation, or favoring by the United States Government or any agency thereof or its contractors or subcontractors.

Printed in the United States of America. Io obtain copies of this document, contact: WHC/BCS Document Control Services, P.0. Box 1970, Mailstop H6-08, Richland WA 99352, Phone (509) 372-2420; Fax (509) 376-4989.
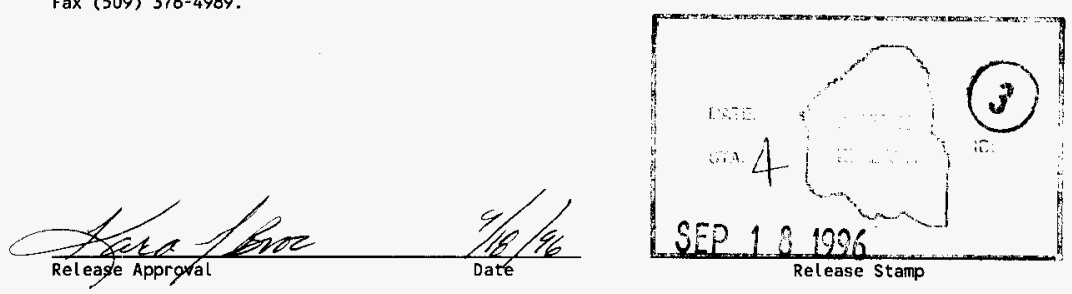

\section{Approved for Public Release}




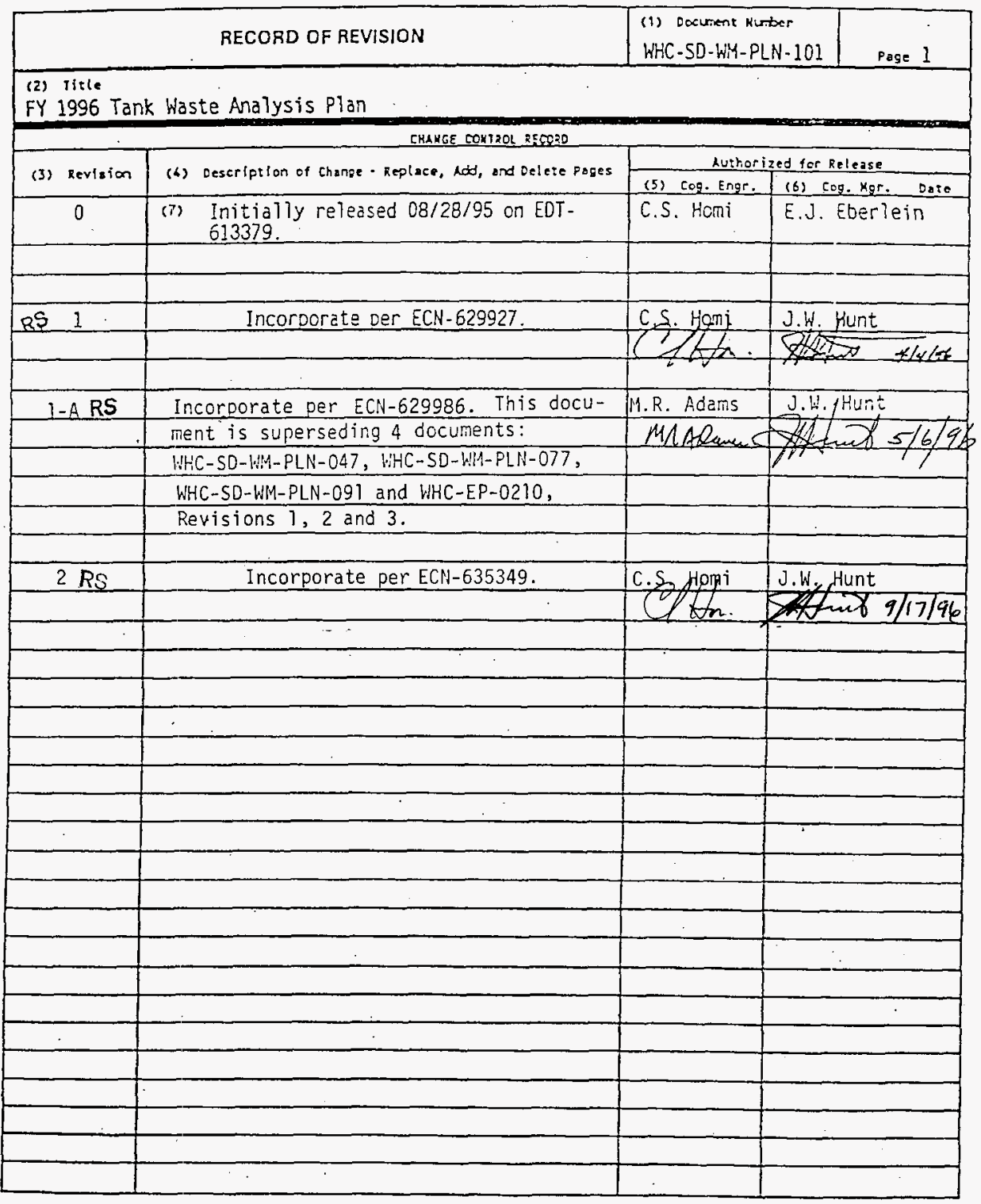


WHC-SD-WM-PLN-101

Revision 2

UC-2070

\title{
FY 1996 Tank Waste Analysis Plan
}

\author{
C. S. Homi
}

J. W. Hunt

Westinghouse Hanford Company

Date Published

September 1996

Prepared for the U.S. Department of Energy Office of Environmental Restoration and Waste Management

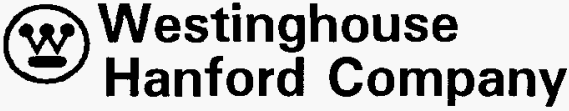

Management and Operations Contractor for the

U.S. Department of Energy under Contract DE-AC06-87RL.10930

Approved for Public Release 
WHC-SD-WM-PLN-101, REV 2

FY 1996 Tank Waste Analysis Plan

TABLE OF CONTENTS

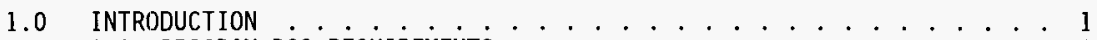

1.1 PROGRAM DQO REQUIREMENTS .................. . . 1

1.2 PROGRAMS SUPPORTED BY THIS TWAP ............ . . 1

1.3 OVERALL TANK WASTE GENERIC ANALYSIS REQUIREMENTS . . . . . . 2

1.4 TANK WASTE GENERIC ANALYSIS REQUIREMENTS FOR SPECIFIC TANK

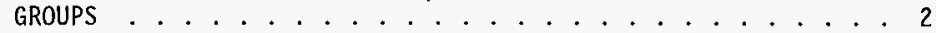

1.5 TANK WASTE CHARACTERIZATION BASIS ............. 4

1.6 TWAP CONTENTS .................. . . 5

2.0 TANK CHARACTERIZATION PLAN . . . . . . . . . . 5

2.1 BASIS FOR TANK CHARACTERIZATION PLANS .......... 5

2.2 TANK CHARACTERIZATION PLAN LIST ............. 5

3.0 TANK CHARACTERIZATION REPORT ................... 5

3.1 PURPOSE AND CONTENT OF TANK CHARACTERIZATION REPORTS $\cdots \cdots$

3.2 TCRS SCHEDULED FOR FY $1996 \ldots \ldots \ldots \ldots$

3.3 CHARACTERIZATION FOCUS ................. . . . 7

3.4 DATA RESTRICTION FOR TCR . . . . . . . . . . . . . . . . . 7

4.0 SCHEDULES . . . . . . . . . . . . . . . 8

4.1 OVERALL SAMPLING SCHEDULE $\ldots$

4.2 DEVIATIONS AND CHANGE CONTROL . . . . . . . . . . . . . 8

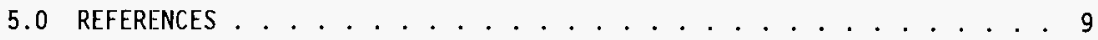

\section{APPENDICES}

Appendix A. TANK CHARActerization Plan CONTENT . . . . . . . . . . A-1

Appendix B. FISCAL YeAR 1996 TANK CHARACTERIZATION PLAN LIST . . . . . . B-1

Appendix $C$. TANK CHARACTERIZATION REPORT CONTENT . . . . . . . . . . . C-1

Appendix D. TANK CHARACTERIZATION REPORTS PLANNED FOR FISCAL YEAR 1996 - D-l

Appendix E. LEVEL 1 TANK SAMPLING SCHEDULE . . . . . . . . . . . . . E-1 
WHC-SD-WM-PLN-101, REV 2

FY 1996 Tank Waste Analysis Plan

\section{LIST OF ACRONYMS}

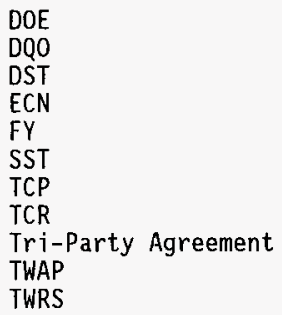

U.S. Department of Energy

Data Quality Objective

Double-Shel1 Tank

Engineering Change Notice

Fiscal Year

Single-Shell Tank

Tank Characterization Plan

Tank Characterization Report

Hanford Federal Facility Agreement and Consent Order Tank Waste Analysis Plan

Tank Waste Remediation System 
WHC-SD-WM-PLN-101, REV 2

FY 1996 Tank Waste Analysis Plan

\subsection{INTRODUCTION}

This Tank Waste Analysis PTan (TWAP) describes the activities of the Tank Waste Remediation System (TWRS) Characterization Project to plan, schedule, obtain, and document characterization information on Hanford waste tanks. This information is required to meet several commitments of Programmatic End-Users and the Hanford Federal Facility Agreement and Consent Order (Ecology et a1. 1994), also known as the Tri-Party Agreement. This TWAP applies to the activities scheduled to be completed in fiscal year 1996 .

\subsection{PROGRAM DQO REQUIREMENTS}

Each TWRS engineering, operating, and safety program is charged with the responsibility for evaluating information needs to safely operate and monitor facilities that store, receive, retrieve, treat, or dispose of waste materials. Information required by each program is assembled and documented through the Data Quality Objective (DQO) process (EPA 1994). DQ0 process documentation defines information needs, information use, data quality, boundary requirements, and special handling requirements pertinent to sampling and analyses to be performed.

The TWRS Characterization Project assembles the requirements for information into specific instructions for sampling and analyses to produce the necessary information. DQOS and supplemental requirements documents are 1 isted in the References, Section 5.0.

\subsection{PROGRAMS SUPPORTED BY THIS TWAP}

Current TWRS program needs are, in priority, to first address pertinent safety issues, then ongoing process activities, and finally disposal needs. The timing and priority of each of these activities may change as the overall program progresses. Priority changes will be reflected in revisions to tank specific Tank Characterization Plans (TCPs).

Elements of this TWAP are designed to satisfy requirements of the following safety, operating, and engineering programs:

- Safety Programs and those subordinate organizations addressing specific safety issues include Ferrocyanide (Meacham et a1. 1995), Organic (Turner et al. 1995), Flammable Gas (McDuffie 1995), Vapor (Osborne et a). 1995), and generic Safety Screening (Dukelow et al. 1995 and Babad et al. 1995). DQOs as cited have been issued to address the information needed to support resolution of each of these safety issues.

- TWRS Plant Project is responsible for receipt of wastes from operating facilities, salt we1l pumping, and transfers of waste tank contents within the tank farms. A Compatibility DQO (Fowler 1995) has been issued which establishes decision rules used to evaluate important characteristics of wastes before transfers and acceptance for storage. 
WHC-SD-WM-PLN-101, REV 2

FY 1996 Tank Waste Analysis Plan

- Other programs include Retrieval, Pretreatment, and Disposal.

Pretreatment and Disposal DQO (Slankas et a1. 1995) and Strategy (Kupfer et al. 1995) plus the Retrieval DQO (Bloom et al. 1995) were issued in

FY 1995.

\subsection{OVERALL TANK WASTE GENERIC ANALYSIS REQUIREMENTS}

Double Shell Tanks (DSTs) and Single Shell Tanks (SSTs) will be sampled and analyzed to provide data to mitigate and/or close safety issues. The Tank Safety Screening Data Quality Objectives (Babad et al. 1995 or Dukelow et al. 1995, depending on date of sampling), hereafter referred to as Safety Screening DQO, initiates the analyses for safety issues. The Data Quality Objectives for Generic In-Tank Health and Safety Vapor Issue Resolution (Osborne 1995), hereafter referred to as Vapor Issue DQO, also applies. The need for this DQO is assessed on a tank-by-tank basis.

To meet the sampling and analytical requirements for the Safety Screening DQO, a minimum of two vertical profiles of the waste will be obtained, one each from two widely-spaced risers. These profiles may be obtained using core, auger, or grab samples. The primary analytical requirements for the safety screening of a tank (Babad et al. 1995) are energetics, moisture (water), total alpha activity, and flammable gas concentrations. Dukelow et al. uses moisture not as a primary analyte, but for correction of energetics to a dry basis. Dukelow et al. also requires density measurement for conversion of total alpha to units of $\mathrm{g} / \mathrm{L}$. Secondary safety screening analyses may be required, depending upon results from the primary analyses. Secondary analyses may include total organic carbon, total cyanide and/or specific radionuclides.

Data may be needed for the Vapor Issue DQO to identify and quantify both flammable and toxic constituents of Hanford tank headspaces. Resolution of these two issues involves a sequence of sampling events and will be assessed on a tank-by-tank basis. The first step may involve a qualitative assessment of a tank's headspace vapor flammability. Further samples may be taken to determine the composition and concentration of specific flammable constituents. Following resolution of the flammability issue, tank headspace samples may be taken to assess vapor toxicity. Samples are taken from a single location at or near the midpoint of the tank's headspace, below the riser.

\subsection{TANK WASTE GENERIC ANALYSIS REQUIREMENTS FOR SPECIFIC TANK GROUPS}

Tanks on the Ferrocyanide Watch List will be sampled and analyzed as per Data Requirements for the Ferrocyanide Safety Issue Developed Through the Data Quality Objectives Process (Meacham et a1. 1995), hereafter referred to as Ferrocyanide DQO. Organic Watch List SSTs sampling and analys is activities are addressed in Data Quality Objective to Support Resolution of the Organic Complexant Safety Issue (Turner et al. 1995), hereafter referred to as Organic DQ0. Flammable gas requirements for DST core samples are discussed in Data Requirements for Core Sample Analysis Developed Through the Data Quality 
WHC-SD-WM-PLN-101, REV 2

FY 1996 Tank Waste Analysis Plan

Objectives Process (McDuffie 1995), hereafter referred to as Flammable Gas DQO. Potential waste compatibility analytical needs to address transfer into and within the DST system are addressed in Data Quality Objective for Waste Compatibility Program (Fowler 1995). Pretreatment and disposal data needs are discussed in Data Needs and Attendant Data Quality Objectives for Tank Waste Pretreatment and Disposal (Slankas et a1. 1995) and Strategy for Sampling Hanford Site Tank Wastes for Development of Disposal Technology (Kupfer et al. 1995). Retrieval needs are discussed in Characterization Data Needs for Development, Design, and Operation of Retrieval Equipment Developed Through the Data Quality Objective Process (Bloom and Nguyen 1995). The Historica7 Model Evaluation Data Requirements DQO (Simpson and McCain 1995), hereafter referred to as the Historical DQO, identifies information needed to evaluate the quality of models of tank composition developed from process records.

The Ferrocyanide DQO is used as a guide for characterizing tanks on the Ferrocyanide Watch List. It concludes that the most reliable information will be obtained from core samples and that an average of two core samples taken from risers separated by maximum distances will provide characterization data of sufficient quality to enable decision makers to confidently resolve the safety issues associated with these tanks. Primary parameters, fuel concentration (energetics), moisture content, nickel content and nickel/fuel will be used to support determination of the safety status of a tank.

The Flammable Gas DQO is primarily concerned with the potential for retained gas in DST Watch List tanks. Physical, chemical, and radiochemical measurements of core samples are additional concerns.

The Organic DQO focuses on tanks that contain or may contain, based on safety screening, organic compounds above the established decision thresholds. It identifies the information needed to assess if tanks should be removed from, not removed from, or added to the Organic Watch List. As with the ferrocyanide DQO effort, the sampling and analyses prescribed by this DQO will support safety classification of these tanks. The sampling requirements of the organic DQO are for a minimum of two profiles separated to the maximum extent possible by existing risers. Application of this DQO to non-Organic Watch List tanks is discussed in Preliminary Safety Criteria for Organic Watch List Tanks at the Hanford Site (Webb et a1. 1995)

The Pretreatment Strategy has prioritized 47 SSTs and 12 DSTs for sampling and characterization to support key TWRS decisions associated with both pretreatment and vitrification. The strategy outlines the process testing that will be performed on waste samples. Only the sample material is provided by the Characterization project. No analyses are required. Tank sample selections based on historical sources are being confirmed by the Historical DQO. In addition to the tanks specified in the strategy, sample material from other tanks may be supplied to the pretreatment/disposal programs to augment their information base.

The Historical $\mathrm{DQO}$ has identified 20 bounding tanks, plus alternatives to each. The DQO identifies the acquisition and analys is of samples from each of these tanks to determine the range of composition encountered in each of the major waste types which have contributed to the overall tank contents. The identified analyses provide measurement of primary cations, anions, and radionuclides that bound waste processing and safe storage. The current 
WHC-SD-WM-PLN-101, REV 2

FY 1996 Tank Waste Analysis Plan

version of the $\mathrm{DQO}$ does not specify a requirement for number of samples or a confidence requirement. In addition to the primary bounding tanks identified in the DQO, the historical evaluation analyses may be applied to other tanks to augment the information available regarding waste type composition.

The DQO, Characterization Data Needs for Development, Design, and Operation of Retrieval Equipment Developed Through the Data Quality Objective Process (Bloom and Nguyen 1995), requires sample material from Tank 241-AZ-101 for determining several physical properties. Obtaining sample material from other tanks is not planned at this time.

\subsection{TANK WASTE CHARACTERIZATION BASIS}

The Tank Waste Characterization Basis (Brown et al. 1995) was developed to prioritize tanks for core sampling and to develop a core sampling schedule. The Basis produces technical justification and priorities for core sampling and analyses of a group of tanks. From the group of Basis tanks, the schedule applies operational constraints to determine specific tanks to be sampled. The TWAP is then produced based on the resulting schedule. Data requirements that are met by methods other than core sampling are integrated into the overall schedule. Information gained from the sampling and analys is effort is subsequently used to update the Basis document. The Characterization Basis prioritization process was based on the following seven issues:

- $\quad$ Safety Screening

- Historical

- Ferrocyanide

- Organic

- Flammable Gas

- Retrieval

- $\quad$ Pretreatment

The Safety Screening DQO (Babad et al. 1995) and Pretreatment Strategy (Kupfer et al. 1995) were used for prioritization on all tanks. The Historical DQO was used for all SSTs even though the calculated priority value was zero on many tanks. SST tank specific TCPS reflect the use of the Historical DQO for prioritization purposes, but application of DQO sampling and analysis requirements are applied for specifically identified tanks only. 
WHC-SD-WM-PLN-101, REV 2

FY 1996 Tank Waste Analysis Plan

\subsection{TWAP CONTENTS}

This FY 1996 update of the Tank Waste Analysis Plan outlines in Sections $2.0,3.0$, and 4.0 , the following documents to be produced in FY 1996:

- Tank Characterization Plans (TCPs).

- Tank Characterization Reports (TCRs).

- Sampling schedules (FY 1996 and outyears).

\subsection{TANK CHARACTERIZATION PLAN}

The Tank Characterization Plan (TCP) is the program management plan for a specific tank. It provides an at-time-of-publication schedule of tank characterization activities and a summary of those activities. Past characterization activities are also discussed.

\subsection{BASIS FOR TANK CHARACTERIZATION PLANS}

The basis for selecting tanks to be characterized is resolution of immediate safety issues, verification of assumptions to support safety screening strategies, confirmation of historical data and models, and obtaining of waste samples for process development and testing. The outline for a TCP is shown in Appendix A.

\subsection{TANK CHARACTERIZATION PLAN LIST}

Appendix B contains a listing of specific tank TCPs which are attached as separately released documents and submitted for approval. The TCPs apply to the same tanks for which Tank Characterization Reports (TCRs) will be prepared. Each TCP has been assigned a supporting document number and is issued as a stand-alone document. These plans are provided as part of TriParty Agreement milestone M44-02B.

\subsection{TANK CHARACTERIZATION REPORT}

\subsection{PURPOSE AND CONTENT OF TANK CHARACTERIZATION REPORTS}

The Tank Characterization Report (TCR) addresses all currently developed characterization information about a waste tank and is provided for the further use of end users and stakeholders. The format is standardized to facilitate searches for specific information. The document is built through an iterative process. Available historical records are augmented by results 
WHC-SD-WM-PLN-101, REV 2

FY 1996 Tank Waste Analysis Plan

of current activities (e.g., sampling and analyses since May 1989) and earlier verified data. The document includes a comparison of the current analytical data and historical estimates of chemical inventory and the results of that evaluation. The TCR identifies $D Q O$ and revision numbers applicable at the time the information was gathered.

Issued TCRs will be updated quarterly as needed due to addition and/or removal of tank wastes and as new information is obtained. The outline of a TCR is in Appendix C.

\subsection{TCRS SCHEDULED FOR FY 1996}

Appendix $D$ is a 1 ist, identical in tanks to Appendix B, of 40 TCRs identified to support Tri-Party Agreement Milestone M-44-09. The FY 1996 Multi-Year Program Plan supports only 21 of these TCRs to be issued in FY 1996. It is expected, however, that all 40 TCRs will be submitted in FY 1996 and every effort is being made to accomplish that goal. The listing of TCRs includes those tanks for which sampling and analysis efforts were completed in fiscal year 1995 but were not included in fiscal year 1995 issued TCRs. Some information generated in fiscal year 1996 will not reach documentation in TCRs until fiscal year 1997.

The listed 40 TCRs include only 12 of the 28 tanks which have come to be referred to as the High Priority Tanks. Tables 9-2 and 9-4 of the Tank Waste Characterization Basis (Brown et al. 1995) published in August 1995, identify 28 High Priority Tanks for core sampling, tanks for which it is believed will provide optimal information from sampling and analysis in support of programmatic needs. Due to constraints described below, these 28 tanks have not all been sampled prior to the sampling of other tanks.

Six of the 28 High Priority Tanks were originally scheduled for push mode core sampling. Two of these six tanks have been sampled, B-104, followed by S-107. The other four of the six, AN-101, AN-103, AN-104, and AN-105, require push mode sampling using sampling truck \# 1 with the retained gas sampler (RGS). The RGS became available in January 1996. In order to maintain effective use of sampling crews and systems while awaiting deployment of the RGS, four tanks not on the High Priority list were push mode sampled, $\mathrm{B}-203, \mathrm{~B}-204, \mathrm{BX}-104$, and $\mathrm{BX}-112$. Currently, AW-101 is being push mode sampled with the RGS. The results of this sampling effort will be published in a revision to the AW-101 TCR originally produced in FY 1995. The other three tanks requiring RGS will be sampled following completion of AW-101, but TCRs will not be produced until FY 1997.

The other 22 High Priority tanks were originally scheduled for rotary mode core sampling. Due to subsequently generated flammable gas safety concerns, rotary mode core sampling is not currently authorized in any tanks. However, rotary mode core sampling tests completed on BY-108 and BY-110 in October 1995 revealed that some waste types previously thought to require rotary core sampling, could indeed, be sampled using push mode core sampling instead. Therefore, 10 of the other 22 tanks have been push mode core sampled, with TCRs to be produced in FY 1996 (BY-104, BY-105, BY-106, BY-108, BY-110, S-101, S-102, U-105, U-107, and U-109). Tank S-110 has also been push 
mode core sampled and $\mathrm{U}-108$ is currently being sampled. However, TCRs for tanks S-110 and U-108 will not be produced until FY 1997.

The remaining 10 of the other 22 High Priority tanks are still considered to require rotary mode core sampling which will not become authorized until approval of a safety analysis and modifications to the rotary mode core sampling systems. This authorization is currently expected in August 1996. However, no sampling results will become available in TCRs until FY 1997 . Until rotary mode core sampling can be resumed and the remaining High Priority tanks sampled, alternate tanks, also of high value but not on the list of 28 High Priority tanks have been designated for push mode core sampling (Eberlein 1996).

The following is additional clarification of the TCRs to be produced in FY 1996. Although not prioritized in the core sampling scope of the Tank Waste Characterization Basis (Brown et a1. 1995), 18 tanks will have TCRs produced based on grab and/or auger samples, sampling conducted to permit efficient use of sampling crews. Six other tanks, B-101, B-106, BX-103, BX-109, C-103, and SY-103, will have TCRs produced based on push mode core sampling conducted prior to the August 1995 publication of the Tank Waste Characterization Basis (Brown et a1. 1995).

\subsection{CHARACTERIZATION FOCUS}

Analyses currently in progress are expected to provide sufficient assurance that interim safe storage and later operations, to include retrieval, can be safely performed. When final decisions have been made on the mode of retrieval, further evaluation will be required to assure safety of retrieval operations. Complete characterization of tank waste is likely to not be completed until the waste is retrieved for Pretreatment Processing. At that time, tank contents will theoretically have become homogenized.

\subsection{DATA RESTRICTION FOR TCR}

Tri-Party Agreement milestone change number M-44-93-01 states: "Because data obtained prior to May 1989 did not have quality assurance and quality control assured under the TPA, acceptable characterization data will be based on some sampling and analysis of each waste phase for each DST and SST as specified through the DQO process". Therefore, pre-May 1989 data alone, will not constitute an acceptable TCR; although, such data should be discussed as appropriate. Later solid/liquid phase analyses will be based on core and auger samples, pure liquid phase on grab samples, and vapor phase on vapor samples. 
WHC-SD-WM-PLN-101, REV 2

FY 1996 Tank Waste Analysis Plan

\subsection{SCHEDULES}

\subsection{OVERALL SAMPLING SCHEDULE}

The sampling schedule (Stanton 1996), Appendix E, was developed based on the Tri-Party Agreement milestone M-44-09 which calls for issuing TCRs in accordance with approved TCPs during FY 1996 and beyond to fiscal year 2000 . This Level 1 schedule is consistent with the program management as described in the Tank Waste Characterization Basis (Brown et al. 1995). The schedule is subject to change due to unexpected operational constraints, sampling resource availability, analytical laboratory resource availability, and changes in programmatic priorities.

\subsection{DEVIATIONS AND CHANGE CONTROL}

Scheduled sampling events, the potential for need of issuance of new or revised TCPS, the production of TCRs, and the order in which these events occur are subject to change because of shifting priorities, resource availability, and unexpected operational constraints. It is the intent of the TWRS Characterization Project, however, to accomplish the scope of work indicated by the schedule, within the planned time period. Significant programmatic deviations and changes will be documented by controlled revisions to this plan. Such revisions will be transmitted as Engineering Change Notices (ECNs). These ECNs will provide reasons for the schedule change and the impact to the original schedule. Minor changes such as adding, deleting, or changing sampling order of tanks will be addressed at unit managers meetings, and as required, will be documented by ECNs. 
WHC-SD-WM-PLN-101, REV 2

FY 1996 Tank Waste Analysis Plan

\section{0 REFERENCES}

Babad, H., J. W. Hunt, and K. S. Redus, 1995, Tank Safety Screening Data Quality Objective, WHC-SD-WM-SP-004, Rev 1, Westinghouse Hanford Company, Richland, Washington.

Bloom, G. R. and Q. H. Nguyen, 1995, Characterization Data Needs for Development, Design, and Operation of Retrieval Equipment Developed Through the Data Quality Objective Process, WHC-SD-WM-DQ0-008, Rev. 0, Westinghouse Hanford Company, Richland, Washington.

Brown, T. M., S. J. Eberlein, and T. J. Kunthara, 1995, Tank Waste Characterization Basis, WHC-SD-WM-TA-164, Rev 1, Westinghouse Hanford Company, Richland, Washington.

Dukelow, G. T., J. W. Hunt, H. Babad, and J. E. Meacham, 1995, Tank Safety Screening Data Quality Objective, WHC-SD-WM-SP-004, Rev 2, Westinghouse Hanford Company, Richland, Washington.

Eberlein, S. J., 1996, Characterization Basis Off-Ramp List, (letter to C. P. Bader, DOE-RL, \#9650123, January 30), Westinghouse Hanford Company, Richland, Washington.

Ecology, EPA, and DOE, 1994, Hanford Federal Facility Agreement and Consent Order, Fourth Amendment, Washington State Department of Ecology, U. S. Environmental Protection Agency, and U. S. Department of Energy, 01 ympia, Washington.

EPA, 1994, Guidance for the Data Quality Objectives Process, EPA QA/G-4, U. S Environmental Protection Agency Quality Assurance Management Staff, Washington, D. C.

Fowler, K. D., 1995, Data Quality Objectives for the Waste Compatibility Program, WHC-SD-WM-DQ0-001, Rev. 1, Westinghouse Hanford Company, Richland, Washington.

Kupfer, M. J., W. W. Schulz, and J. T. Slankas, 1995, Strategy for Sampling Hanford Site Tank Wastes for Development of Disposa7 Technology, WHC-SDWM-TA-154, Rev. 1, Westinghouse Hanford Company, Richland, Washington.

McDuffie, N. G., 1995, Flammable Gas Tank Safety Program: Data Requirements for Core Sample Analysis Developed Through the Data Quality Objectives Process, WHC-SD-WM-DQO-004, Rev. 2, Westinghouse Hanford Company.

Meacham, J. E, R. J. Cash, B. A. Pulsipher, and G. Chen, 1995, Data Requirements for the Ferrocyanide Safety Issue Developed Through the Data Quality Objectives Process, WHC-SD-WM-DQ0-007, Rev. 2, Westinghouse Hanford Company, Richland, Washington.

Osborne, J. W., J. L. Huckaby, E. R. Hewitt, C. M. Anderson, D. D. Mahlum, B. A. Pulsipher, and J. Y. Young, 1995, Data Quality Objectives for Generic In-Tank Health and Safety Vapor Issue Resolution, WHC-SD-WM-DQO002, Rev 1, Westinghouse Hanford Company, Richland, Washington. 
Simpson, B. C. and D. J. McCain, 1995, Historical Model Evaluation Data Requirements, WHC-SD-WM-DQ0-018, Rev. 0, Westinghouse Hanford Company, Richland, Washington.

Slankas, J. T., M. J. Kupfer, W. W. Schulz, B. F. Campbel1, D. J. McCain, B. C. Simpson, W. D. Berman, and C. E. Whipple, 1995, Data Needs and Attendant Data Quality Objectives for Tank Waste Pretreatment and Disposal, WHC-SD-WM-DQO-022. Rev 0, Westinghouse Hanford Company, Richland, Washington.

Stanton, G. A., 1996, Baseline Sampling Schedule, Revision 4.6, Westinghouse Hanford Company, Richland, Washington.

Turner, D. A., H. Babad, L. L. Buckley, and J. E. Meacham, 1995, Data Quality objective to Support Resolution of the Organic Complexant Safety Issue, WHC-SD-WM-DQ0-006, Rev. 2, Westinghouse Hanford Company, Richland, Washington.

Webb, A. B., J. L. Stewart, D. A. Turner, M. G. Plys, B. Malinovic, J. M. Grigsby, D. M. Camaioni, P. G. Heasler, W. D. Samuels, and J. J. Toth, 1995, Preliminary Safety Criteria for Organic Watch List Tanks at the Hanford Site, WHC-SD-SARR-033, Rev. 0, Draft, Westinghouse Hanford Company, Richland, Washington. 
WHC-SD-WM-PLN-101, REV 2

FY 1996 Tank Waste Analysis Plan

\section{APPENDICES}


WHC-SD-WM-PLN-101, REV 2 APPENDIX A

FY 1996 Tank Waste Analysis Plan

\section{TANK CHARACTERIZATION PLAN CONTENT}

1.0 INTRODUCTION

2.0 PROGRAM ELEMENTS REQUIRING INFORMATION FOR 241- $X-X X X$

\subsection{GENERAL SAFETY ISSUES}

2.2 SPECIFIC SAFETY ISSUES

2.2.1 Ferrocyanide

2.2.2 Organic

2.2.3 High Heat

2.2.4 Flammable Gas

2.2.5 Vapor

2.2.6 Criticality

2.3 CONTINUING OPERATIONS

2.3. I Compatibility/Stabilization

2.3.2 Evaporator

2.4 DOUBLE-SHELL TANK WASTE ANALYSIS PLAN

2.5 DISPOSAL

2.5.1 Retrieval

2.5.2 Pretreatment/Vitrification

2.6 HISTORICAL MODEL EVALUATION

3.0 HOW INFORMATION WILL BE OBTAINED

4.0 PRIORITY OF INFORMATION REQUIREMENTS

5.0 WHEN INFORMATION IS NEEDED

6.0 REFERENCES

LIST OF TABLES

4-1 Integrated DQO Requirements 
WHC-SD-WM-PLN-101, REV 2 APPENDIX B

FY 1996 Tank Waste Analysis Plan

FISCAL YEAR 1996 TANK CHARACTERIZATION PLAN LIST

\begin{tabular}{||l|l|l||}
\hline \multicolumn{1}{|c|}{ Tank } & P1 anned DQ0 Analyses* & TCP Document Number \\
\hline \hline A-102 & 6 & WHC-SD-WM-TP-358 R4 \\
\hline AN-101 & 6,7 & WHC-SD-WM-TP-413 R3 \\
\hline AN-102 & 6,7 & WHC-SD-WM-TP-216 R4 \\
\hline AN-106 & 6 & WHC-SD-WM-TP-407 R3 \\
\hline AN-107 & 6,7 & WHC-SD-WM-TP-215 R4 \\
\hline AP-104 & $6,7,9$ & WHC-SD-WM-TP-414 R3 \\
\hline AP-108 & 6,7 & WHC-SD-WM-TP-419 R3 \\
\hline AY-101 & $6,7,9$ & WHC-SD-WM-TP-406 R3 \\
\hline B-101 & 6 & WHC-SD-WM-TP-350 R4 \\
\hline B-104 & 5,6 & WHC-SD-WM-TP-349 R4 \\
\hline B-106 & 5,6 & WHC-SD-WM-TP-353 R4 \\
\hline B-203 & 6 & WHC-SD-WM-TP-354 R3 \\
\hline B-204 & 6 & WHC-SD-WM-TP-355 R3 \\
\hline BX-103 & 6 & WHC-SD-WM-TP-339 R4 \\
\hline BX-104 & 3,6 & WHC-SD-WM-TP-296 R4 \\
\hline BX-106 & 6,7 & WHC-SD-WM-TP-240 R4 \\
\hline BX-109 & 5,6 & WHC-SD-WM-TP-338 R4 \\
\hline BX-110 & $3,5,6$ & WHC-SD-WM-TP-382 R3 \\
\hline BX-112 & 5,6 & WHC-SD-WM-TP-341 R3 \\
\hline BY-104 & $2,5,6$ & WHC-SD-WM-TP-230 R3 \\
\hline BY-105 & $2,5,6,7$ & WHC-SD-WM-TP-218 R4 \\
\hline BY-106 & $2,3,5,6,7$ & WHC-SD-WM-TP-217 R4 \\
\hline BY-108 & $2,3,5,6$ & WHC-SD-WM-TP-275 R4 \\
\hline BY-110 & $2,3,5,6$ & WHC-SD-WM-TP-279 R4 \\
\hline & & \\
\hline
\end{tabular}

* 1=Fl ammable gas; 2=Ferrocyanide; 3=0rganic; 4=Pretreatment; 5=Historical; 6=Safety screening; 7=Compatibility; 8=Retrieval; $9=$ Evaporator; 10=High Heat 
WHC-SD-WM-PLN-101, REV 2 APPENDIX B

FY 1996 Tank Waste Analysis Plan

FISCAL YEAR 1996 TANK CHARACTERIZATION PLAN LIST (cont.)

\begin{tabular}{|l|l|l||}
\hline \multicolumn{1}{|c|}{ Tank } & \multicolumn{1}{|c|}{ Planned DQ0 Analyses* } & TCP Document Number \\
\hline \hline C-103 & 3,6 & WHC-SD-WM-TP-207 R5 \\
\hline C-106 & $6,7,10$ & WHC-SD-WM-TP-212 R4 \\
\hline C-108 & 2,6 & WHC-SD-WM-TP-211 R5 \\
\hline C-204 & 6 & WHC-SD-WM-TP-307 R4 \\
\hline S-101 & 5,6 & WHC-SD-WM-TP-386 R3 \\
\hline S-102 & $3,5,6$ & WHC-SD-WM-TP-238 R3 \\
\hline S-107 & 5,6 & WHC-SD-WM-TP-348 R4 \\
\hline SX-108 & 5,6 & WHC-SD-WM-TP-405 R3 \\
\hline SY-103 & 1,6 & WHC-SD-WM-TP-197 R4 \\
\hline$T-106$ & 6 & WHC-SD-WM-TP-366 R3 \\
\hline T-108 & 5,6 & WHC-SD-WM-TP-367 R3 \\
\hline T-109 & 5,6 & WHC-SD-WM-TP-368 R3 \\
\hline TX-107 & 6 & WHC-SD-WM-TP-420 R3 \\
\hline$U-105$ & $3,5,6,7$ & WHC-SD-WM-TP-289 R3 \\
\hline U-107 & $3,5,6,7$ & WHC-SD-WM-TP-244 R3 \\
\hline$U-109$ & $3,5,6,7$ & WHC-SD-WM-TP-316 R3 \\
\hline
\end{tabular}

* l=Flammable gas; 2=Ferrocyanide; 3=0rganic; 4=Pretreatment; 5=Historical; 6=Safety screening; 7=Compatibility; 8=Retrieval; $9=$ Evaporator; 10=High Heat 
WHC-SD-WM-PLN-101, REV 2 APPENDIX C

FY 1996 Tank Waste Analysis Plan

TANK CHARACTERIZATION REPORT CONTENT

1.0 INTRODUCTION

1.1 PURPOSE

1.2 SCOPE

2.0 HISTORICAL TANK INFORMATION

2.1 TANK STATUS

2.2 TANK DESIGN AND BACKGROUND

2.3 PROCESS KNOWLEDGE

2.3.1 Waste Transfer History

2.3.2 Historical Estimation of Tank Contents

2.4 SURVEILLANCE DATA

2.4.1 Surface Level Readings

2.4.2 Interna1 Tank Temperature

2.4.3 Tank 241-XX-XXX Photographs

3.0 TANK SAMPLING OVERVIEW

3.1 DESCRIPTION OF 19XX SAMPLING EVENT

3.1.1 Sample Handling (19XX)

3.1.2 Sample Analys is (19XX)

3.2 DESCRIPTION OF 19XX SAMPLING EVENT

3.3 HISTORICAL SAMPLING EVENTS

4.0 ANALYTICAL RESULTS AND WASTE INVENTORY ESTIMATES

4.1 DATA PRESENTATION

5.0 INTERPRETATION OF CHARACTERIZATION RESULTS

5.1 ASSESSMENT OF SAMPLING AND ANALYTICAL RESULTS

5.1.1 Field Observations

5.1.2 Quality Control Assessment of Analytical Data

5.1.3 Data Consistency Checks

5.2 COMPARISON OF RESULTS FROM DIFFERENT SAMPLING EVENTS

5.3 TANK WASTE PROFILE

5.4 COMPARISON OF ANALYTICAL AND TRANSFER HISTORY INFORMATION

5.5 EVALUATION OF PROGRAM REQUIREMENTS

5.5.1 Safety Evaluation

5.5.2 Operational Evaluations (if applicable)

5.5.3 Environmental Evaluation (if applicable)

5.5.4 Process Development Evaluation (if applicable)

5.5.5 Historical Evaluation (if applicable)

6.0 CONCLUSION AND RECOMMENDATIONS

7.0 REFERENCES

APPENDICES (Sampling Event Data, Analytical Procedures, Photographs)(if appl icable) 
WHC-SD-WM-PLN-101, REV 2 APPENDIX D

FY 1996 Tank Waste Analysis Plan

TANK CHARACTERIZATION REPORTS PLANNED FOR FISCAL YEAR 1996

\begin{tabular}{||l|l||}
\hline \multicolumn{1}{|c|}{ Tank } & Sampling Event Type \\
\hline A-102 & Auger, Vapor \\
\hline AN-101 & Grab \\
\hline AN-102 & Grab \\
\hline AN-106 & Grab \\
\hline AN-107 & Grab, Vapor \\
\hline AP-104 & Grab \\
\hline AP-108 & Grab \\
\hline AY-101 & Grab \\
\hline B-101 & Push \\
\hline B-104 & Push \\
\hline B-106 & Push \\
\hline B-203 & Push \\
\hline B-204 & Push \\
\hline BX-103 & Push \\
\hline BX-104 & Push, Vapor \\
\hline BX-106 & Auger, Grab \\
\hline BX-109 & Push \\
\hline BX-110 & Auger, Rotary in 10/98 \\
\hline BX-112 & Push, Auger \\
\hline BY-104 & Push, Vapor \\
\hline BY-105 & Rotary ${ }^{1}$, Grab, Vapor $^{2}$, Vapor \\
\hline BY-106 & Rotary/Push ${ }^{3}$ Ruger, Vapor \\
\hline BY-108 & Rotary/Push ${ }^{2}$ Augor \\
\hline BY-110 & Rotary/Push ${ }^{4}$, Vapor \\
\hline \hline & \\
\hline
\end{tabular}

1. One partial core: started in push mode, switched to rotary mode midway, then switched back to push. Incomplete core recovery.

2. Two rotary and one push cores taken.

3. Four rotary and two push cores taken.

4. Three rotary, six push, and one unspecified cores taken. 
WHC-SD-WM-PLN-101, REV 2 APPENDIX D

FY 1996 Tank Waste Analysis Plan

TANK CHARACTERIZATION REPORTS PLANNED FOR FISCAL YEAR 1996 (Cont.)

\begin{tabular}{|l|l|}
\hline Tank & Sampling Event Type \\
\hline \hline C-103 & Push, Vapor \\
\hline C-106 & Grab, Vapor \\
\hline C-108 & Auger, Vapor \\
\hline C-204 & Auger \\
\hline S-101 & Push, Vapor \\
\hline S-102 & Push, Vapor \\
\hline S-107 & Push \\
\hline SX-108 & Auger, Rotary in 10/97 \\
\hline SY-103 & Push \\
\hline T-106 & Auger \\
\hline T-108 & Auger \\
\hline T-109 & Auger \\
\hline TX-107 & Auger \\
\hline U-105 & Push ${ }^{2}$, Grab, Vapor \\
\hline U-107 & Push $^{2}$, Grab, Vapor \\
\hline U-109 & Push, Grab, Vapor \\
\hline
\end{tabular}

1. One core only.

2. Partial core recoveries. 
WHC-SD-WM-PLN-101, REV 2 APPENDIX E

Sampling Schedule: Subject to Change

LEVEL 1 TANK SAMPLING SCHEDULE

A LEVEL 1 BASELINE SAMPLING SCHEDULE (Stanton 1996) DATED MARCH 4, 1996, FOLLOWS. THIS SCHEDULE IS SUBJECT TO CHANGE BASED ON UNEXPECTED OPERATIONAL CONSTRAINTS, CHANGED PRIORITIES, OR RESOURCE AVAILABILITY. 
WHC-SD-WM-PLN-101, REV 2 APPENDIX E

Sampling Schedule: Subject to Change

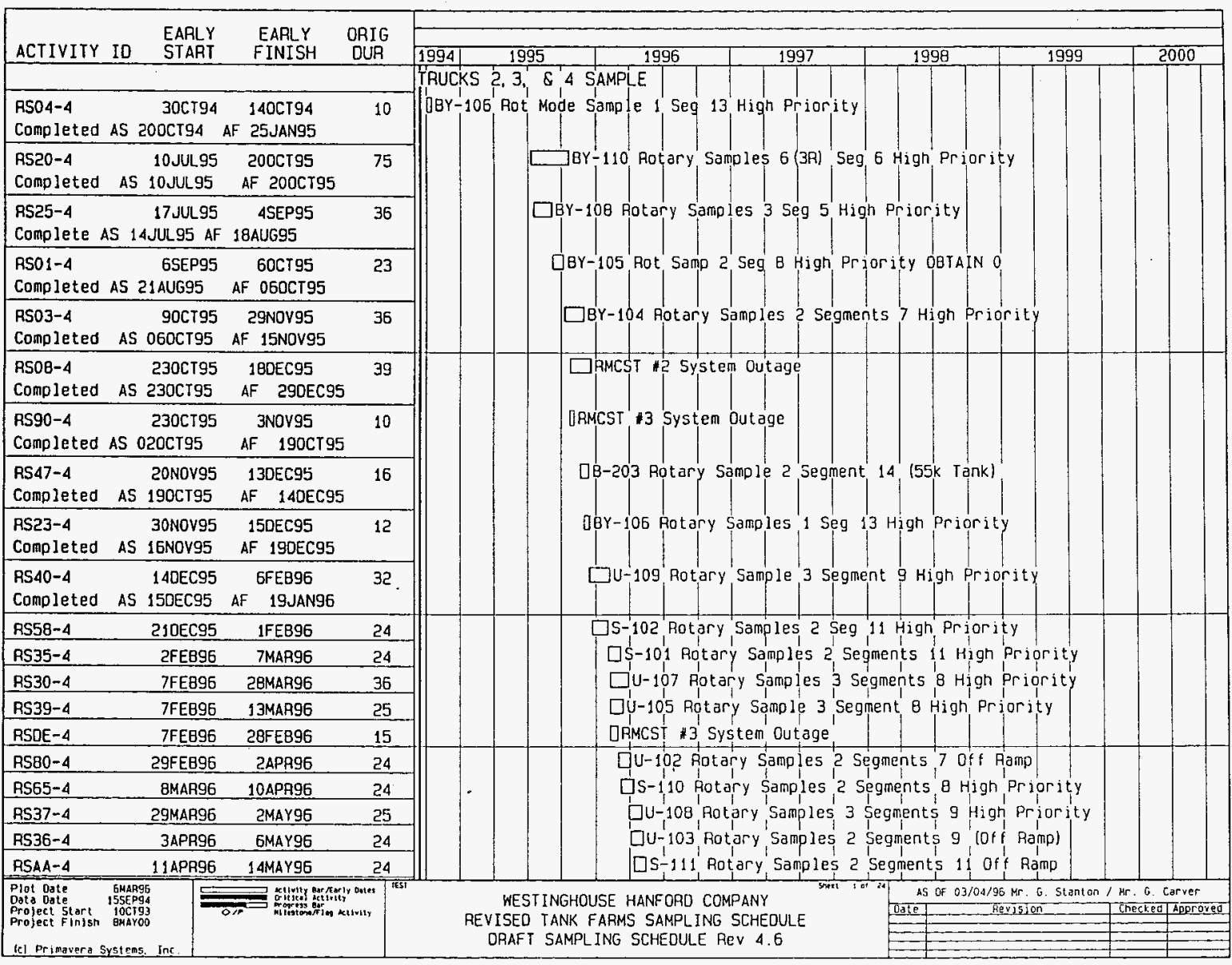


WHC-SD-WM-PLN-101, REV 2 APPENDIX E

Sampling Schedule: Subject to Change

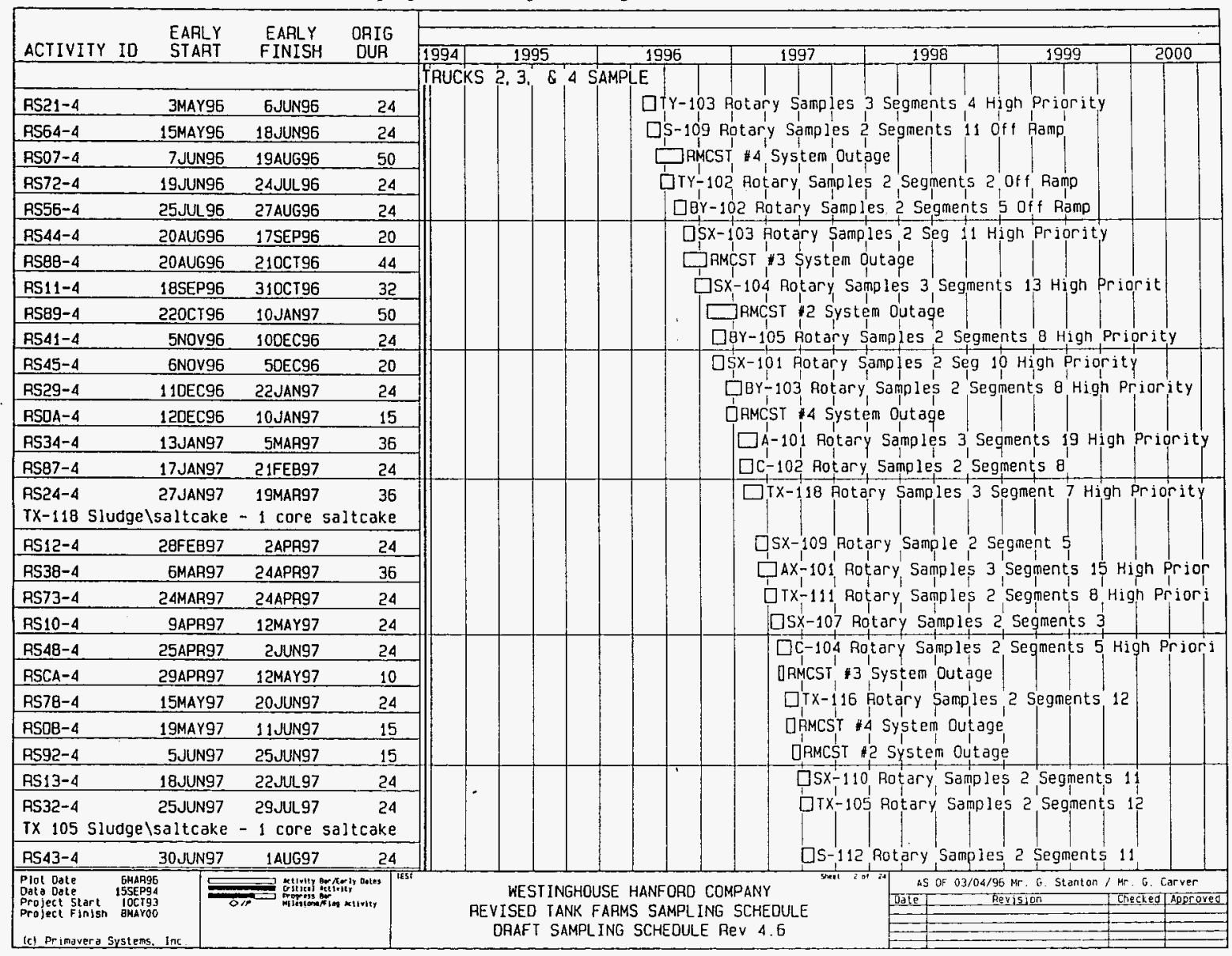


WHC-SD-WM-PLN-101, REV 2 APPENDIX E

Sampling Schedule: Subject to Change

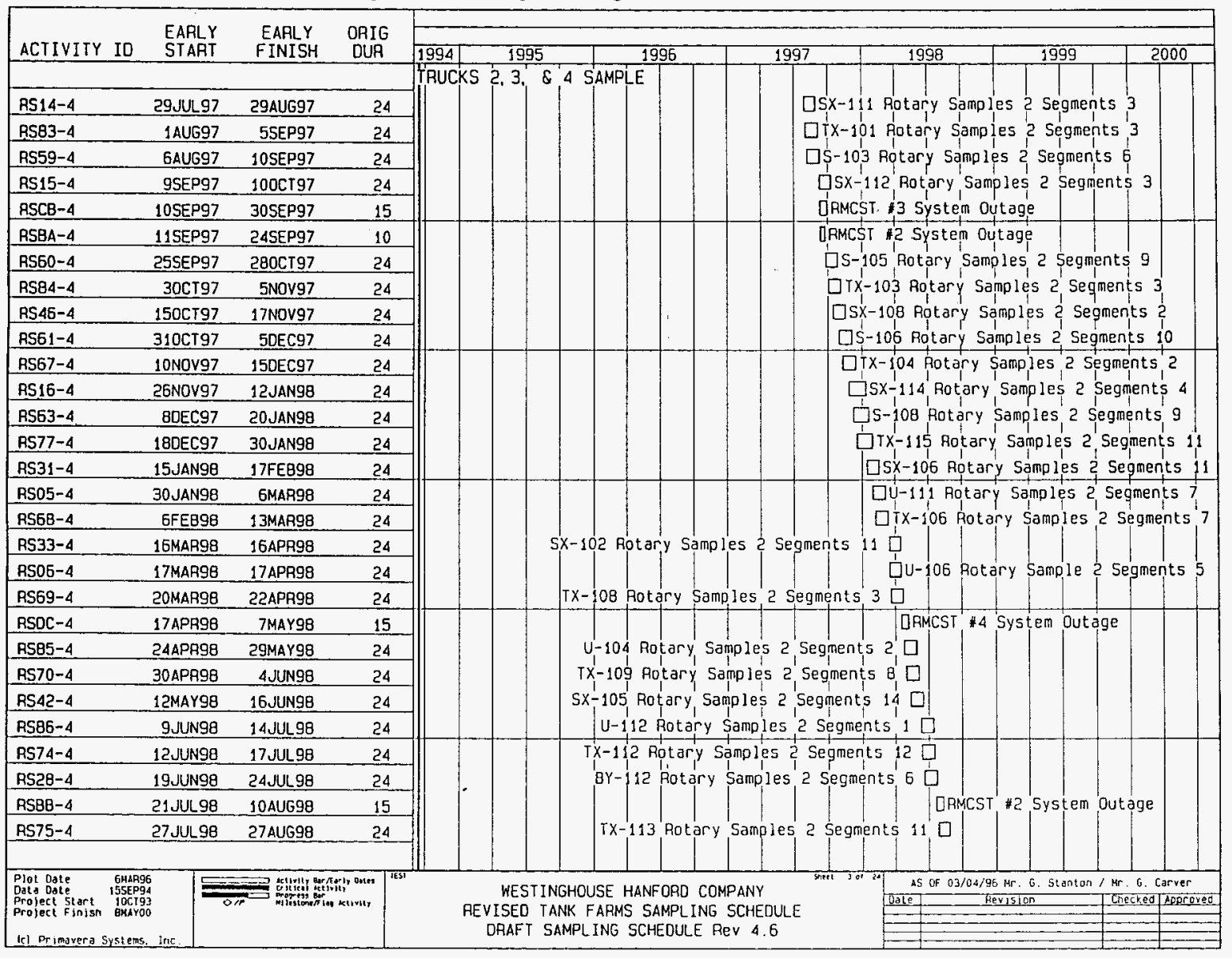


WHC-SD-WM-PLN-101, REV 2 APPENDIX E

Sampling Schedule: Subject to Change

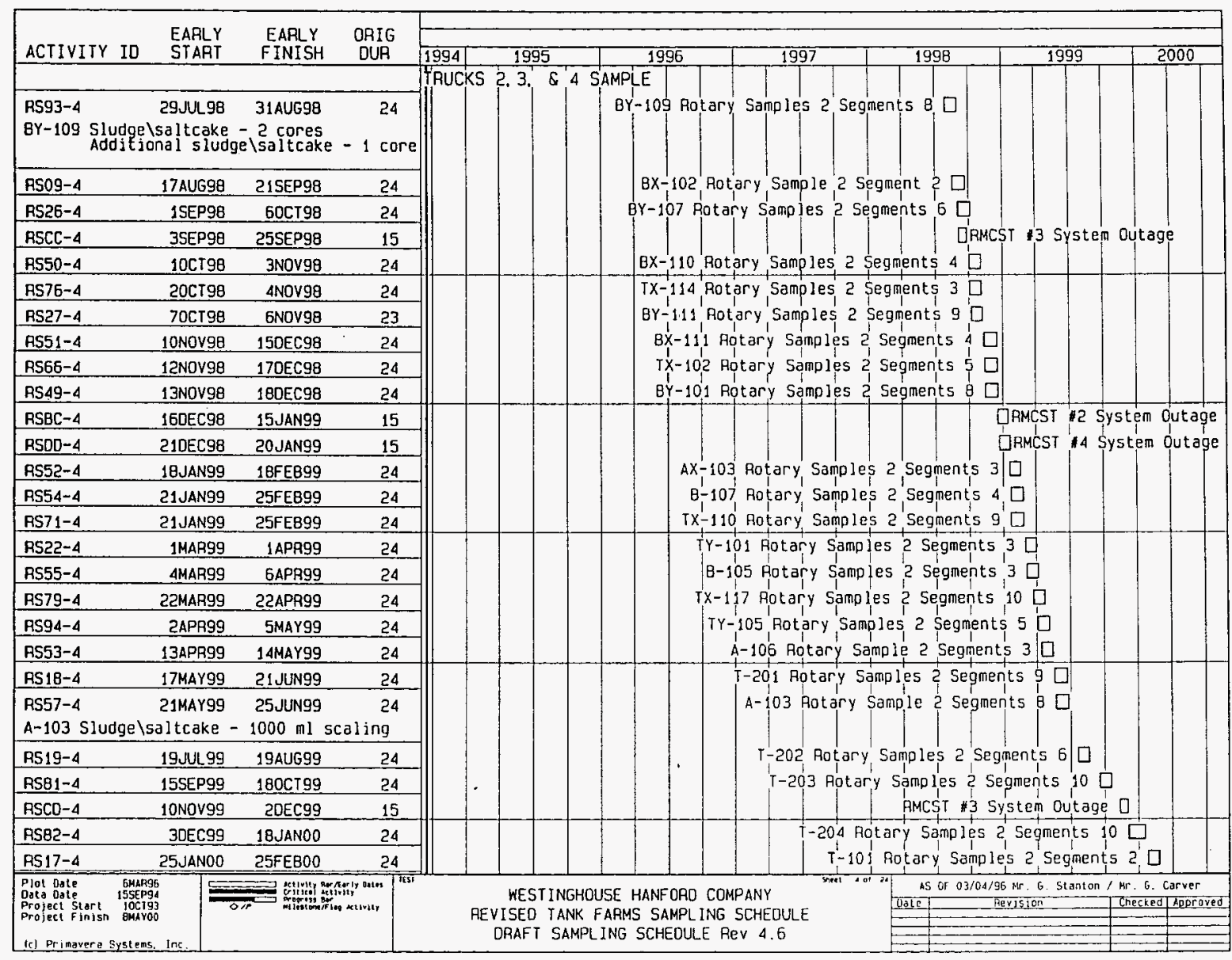


WHC-SD-WM-PLN-101, REV 2 APPENDIX E

Sampling Schedule: Subject to Change

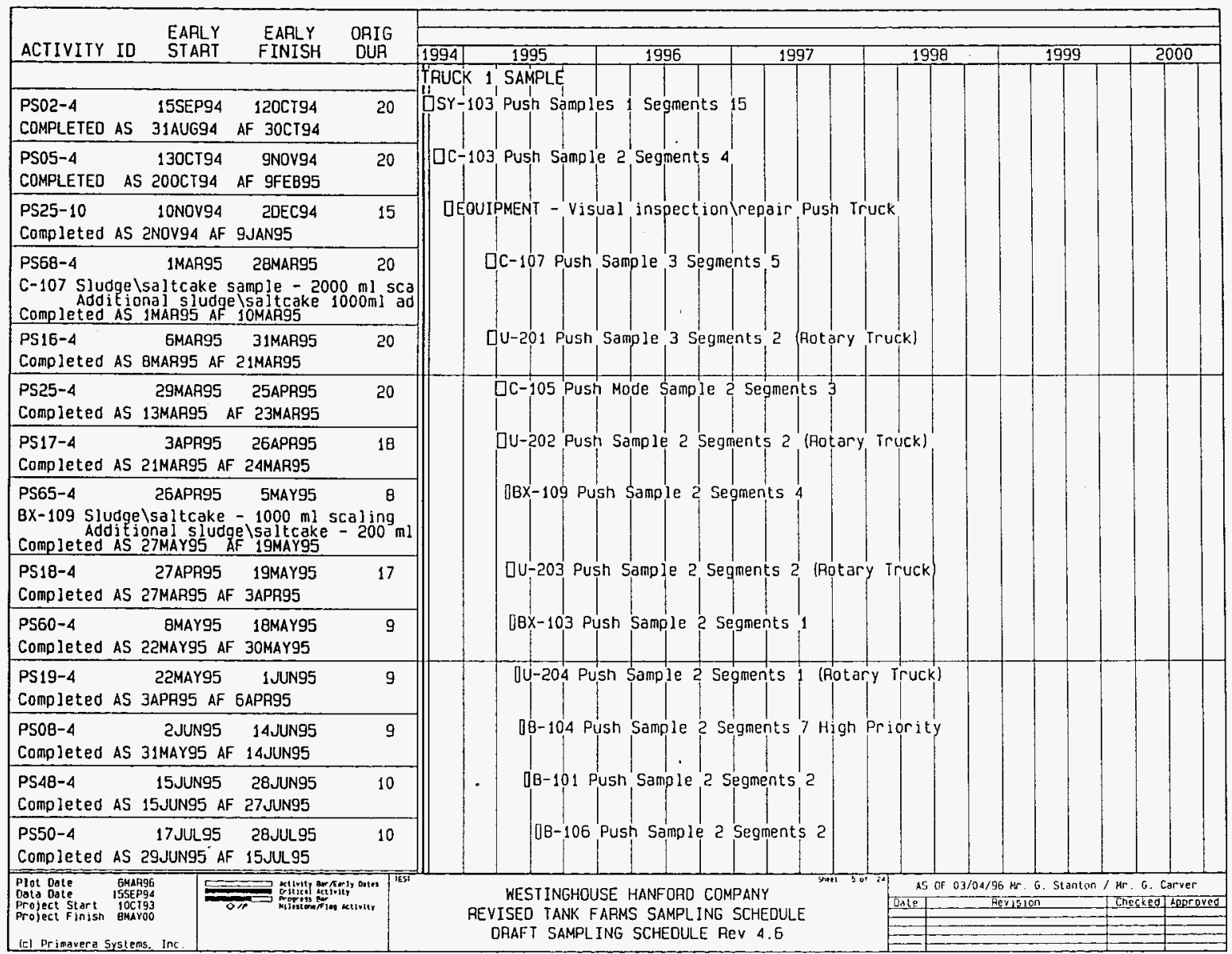


WHC-SD-WM-PLN-101, REV 2 APPENDIX E

Sampling Schedule: Subject to Change

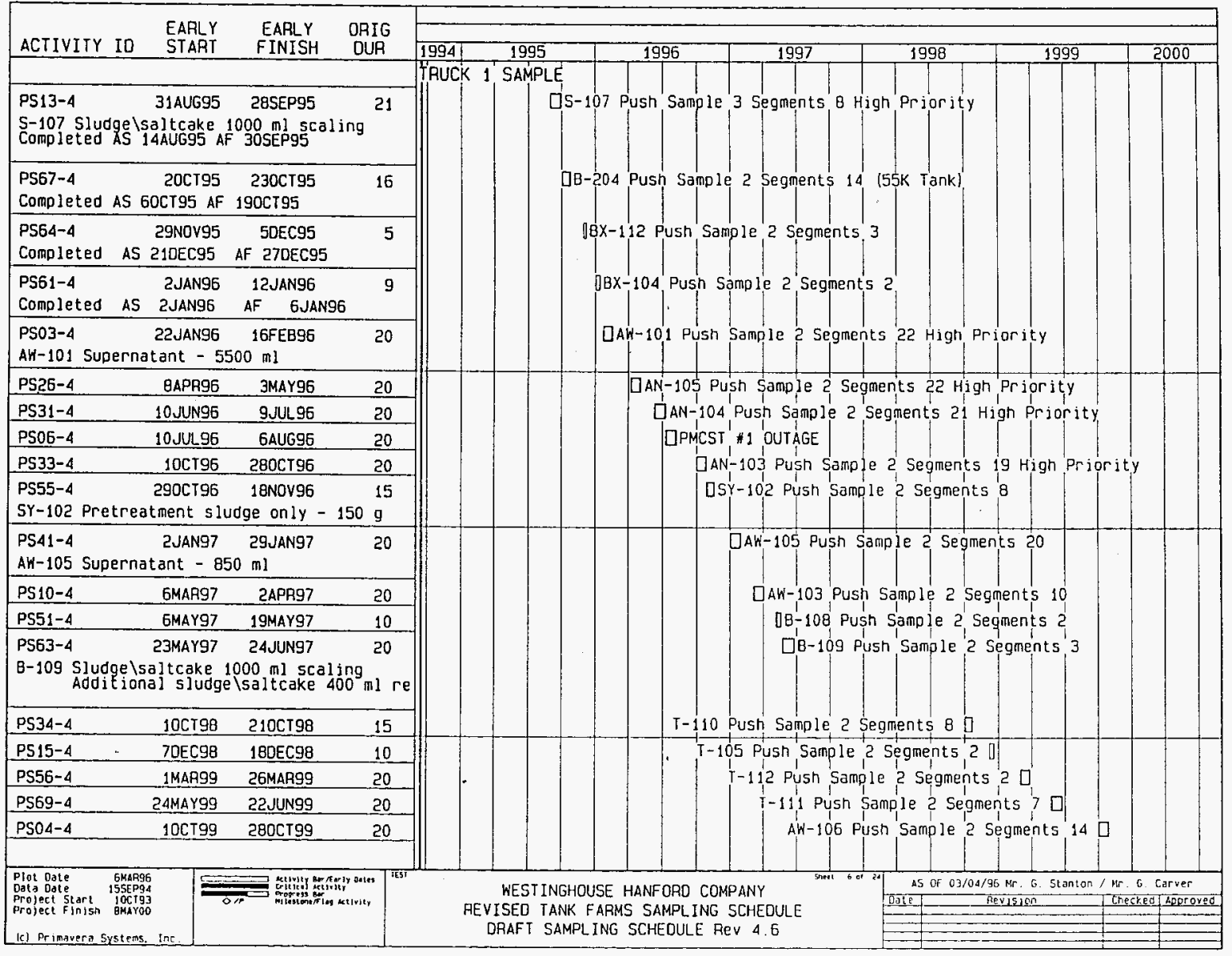




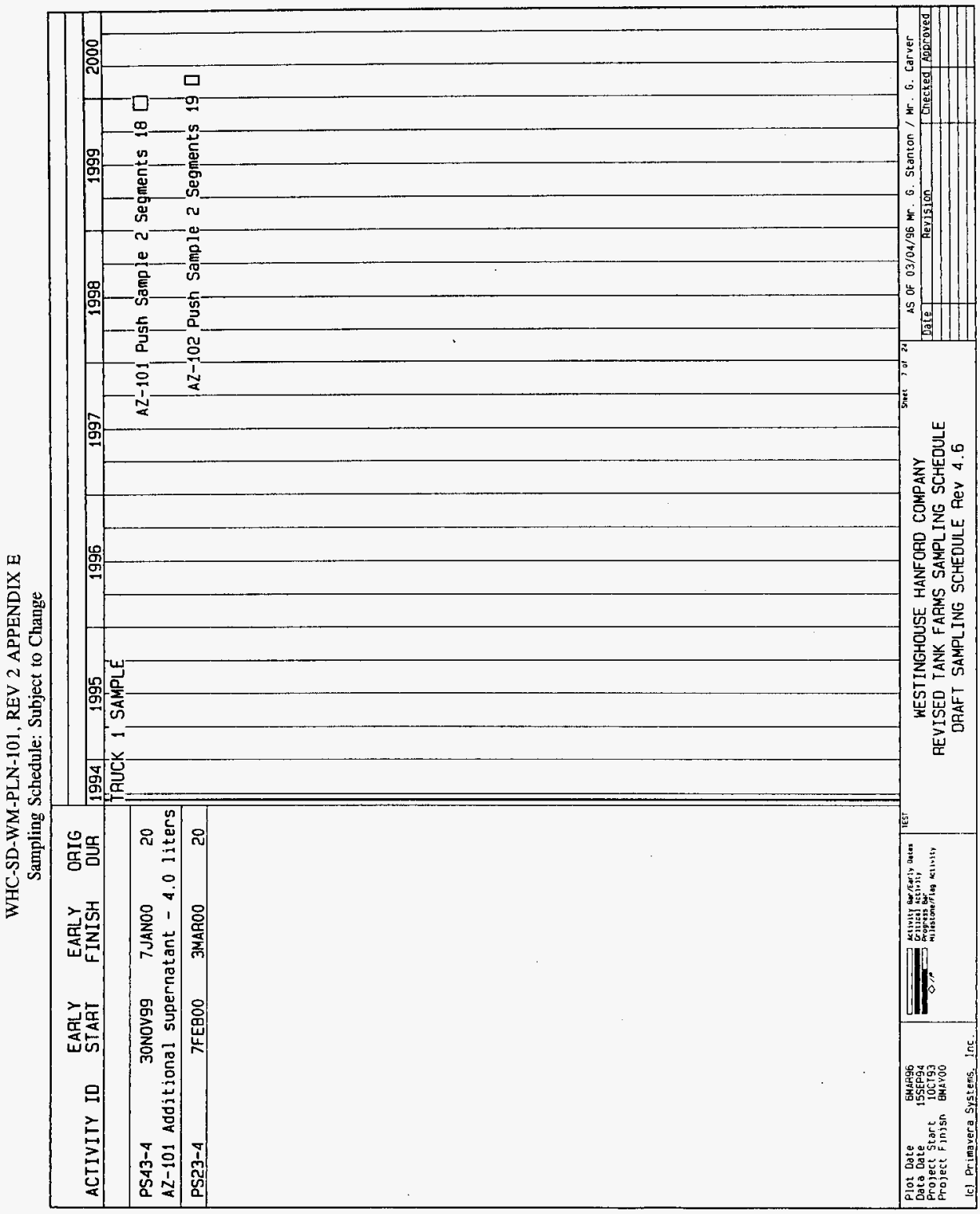


WHC-SD-WM-PLN-101, REV 2 APPENDIX E

Sampling Schedule: Subject to Change

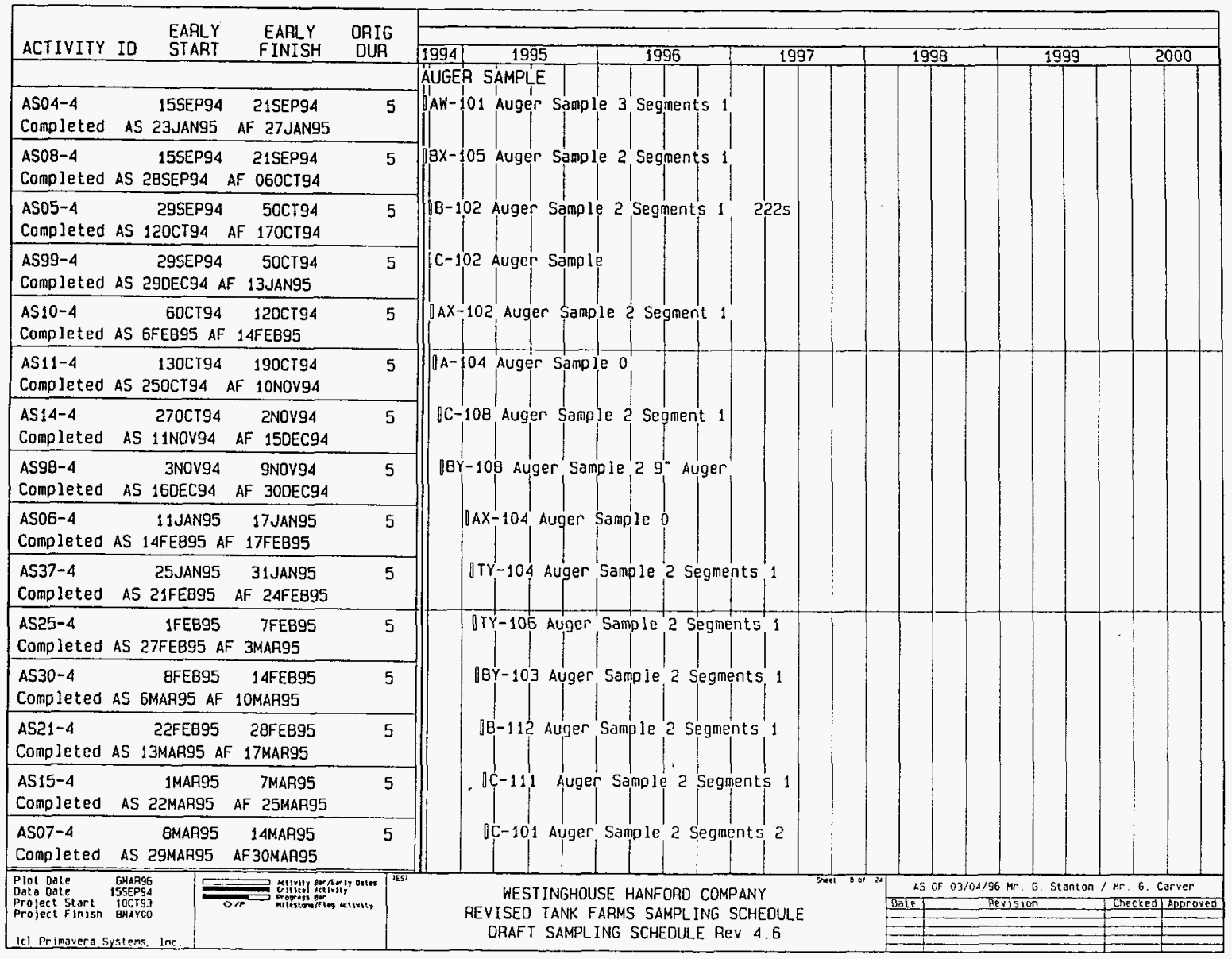


WHC-SD-WM-PLN-101, REV 2 APPENDIX E

Sampling Schedule: Subject to Change

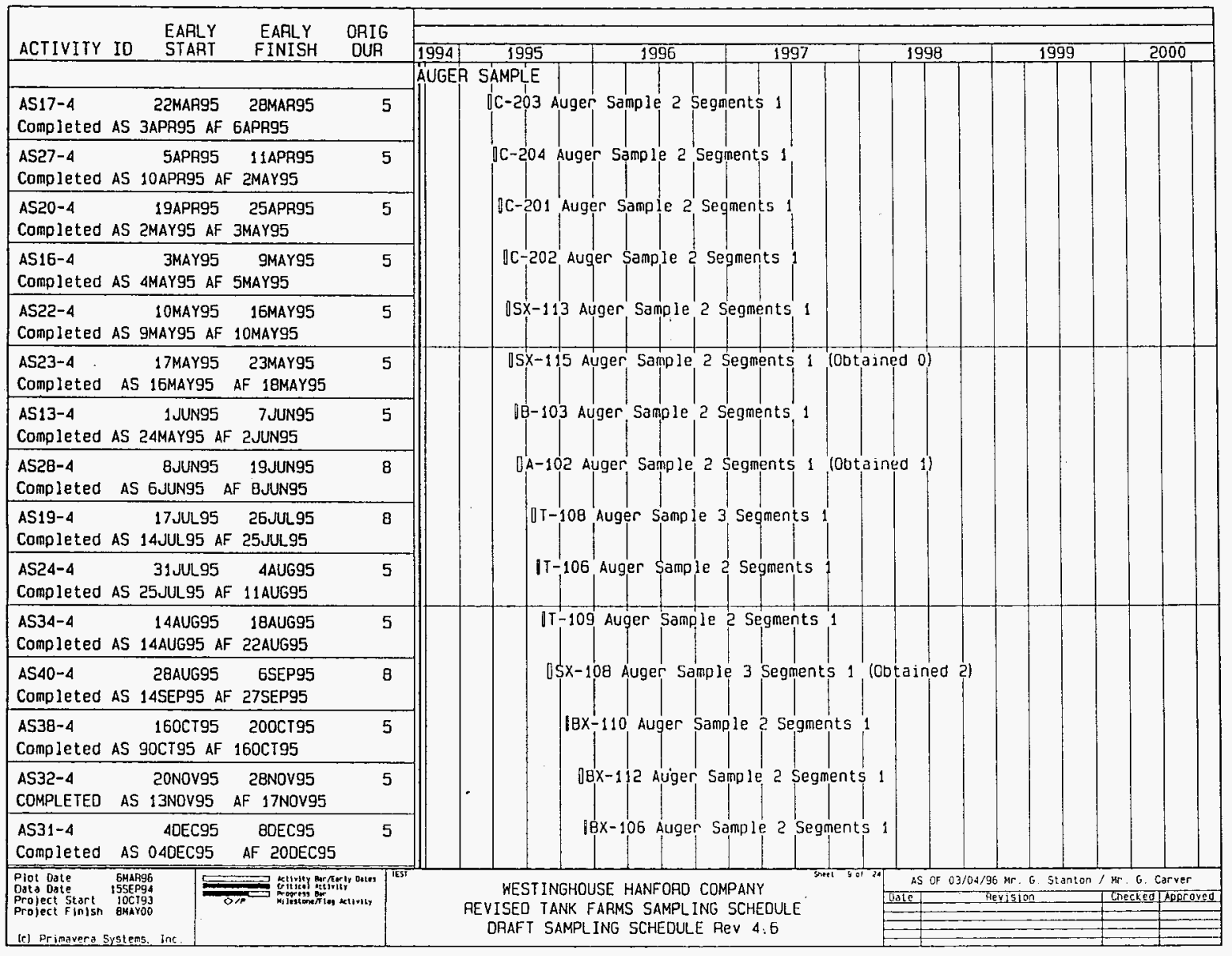


WHC-SD-WM-PLN-101, REV 2 APPENDIX E

Sampling Schedule: Subject to Change

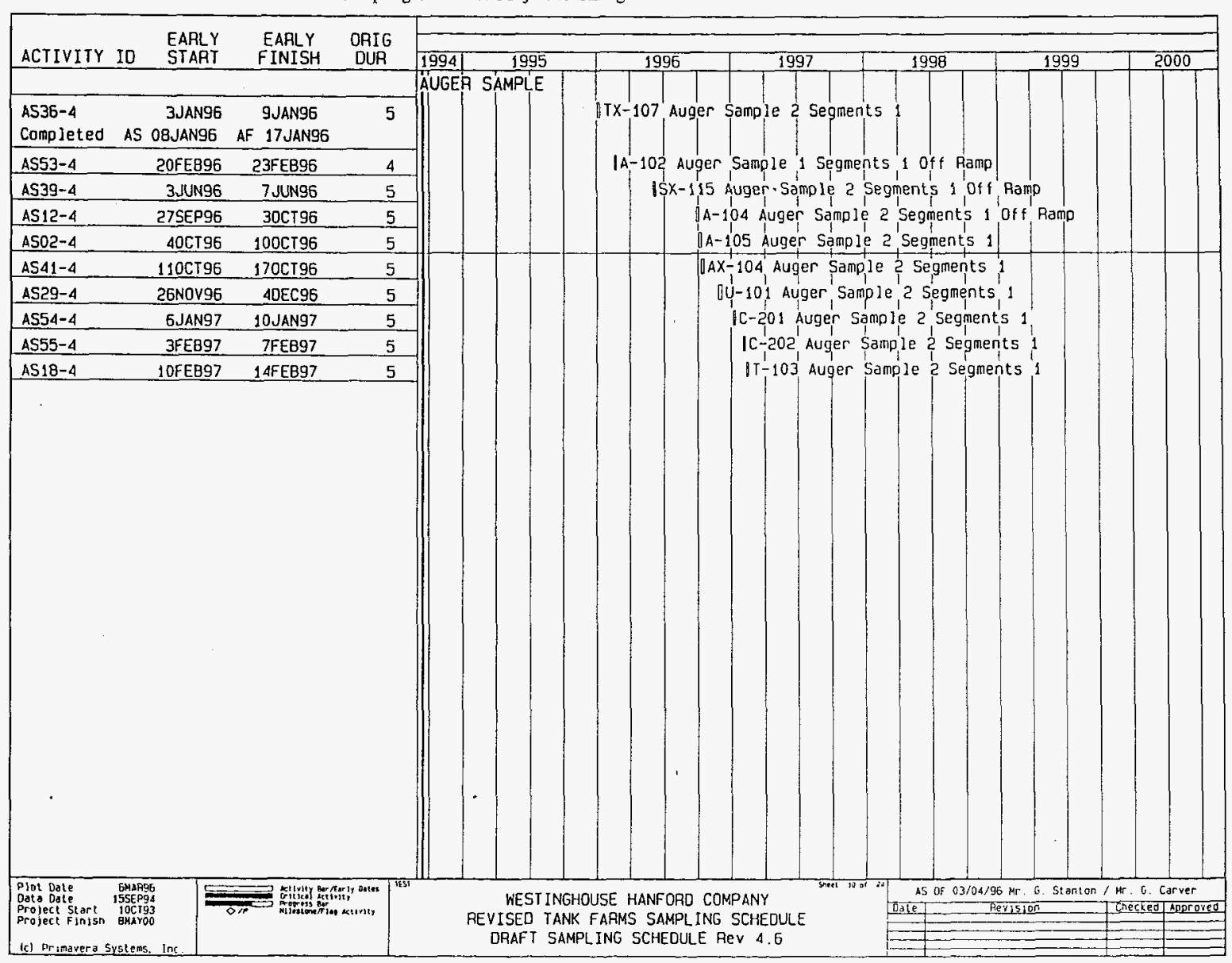




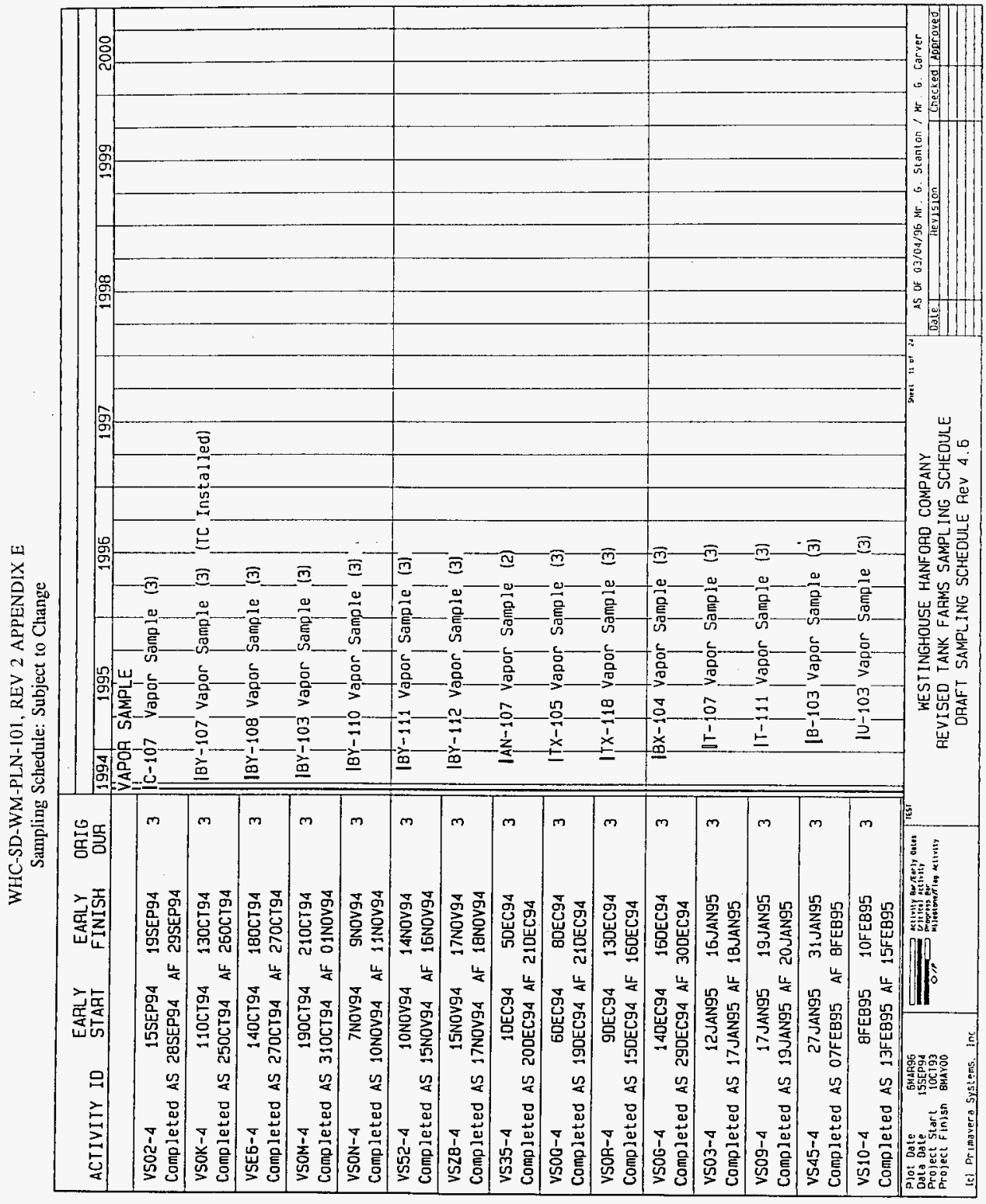




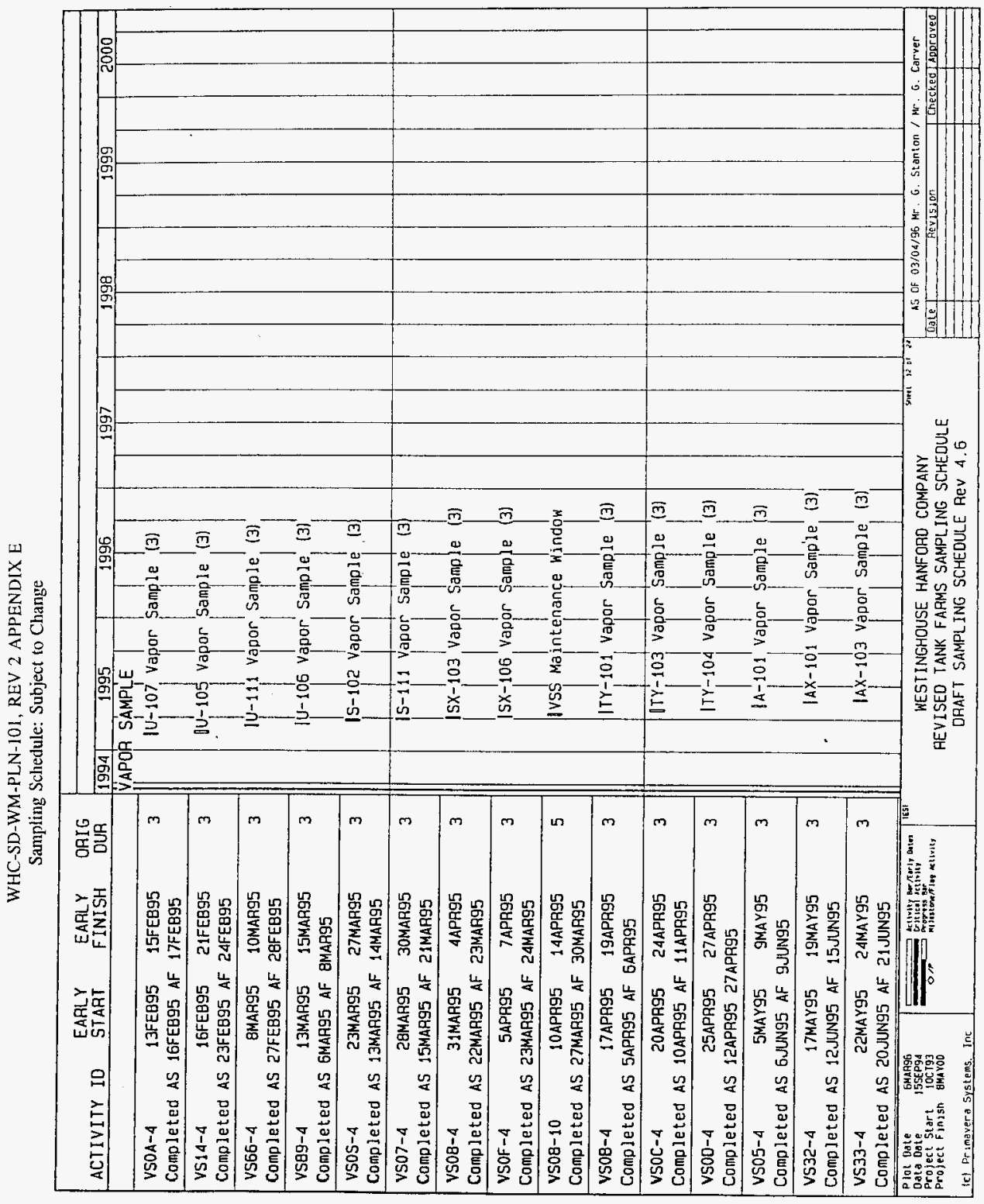




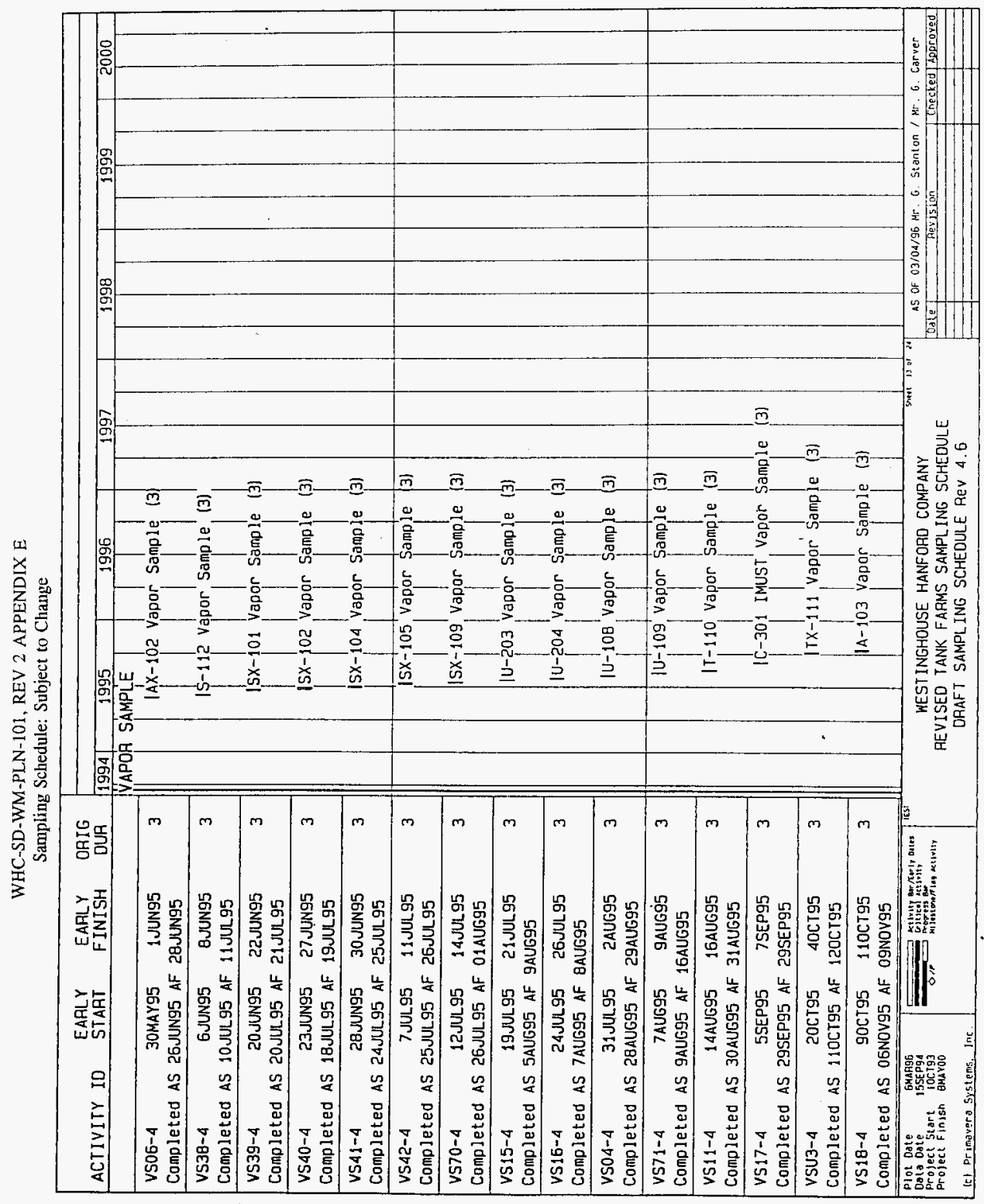


WHC-SD-WM-PLN-101, REV 2 APPENDIX E

Sampling Schedule: Subject to Cliange

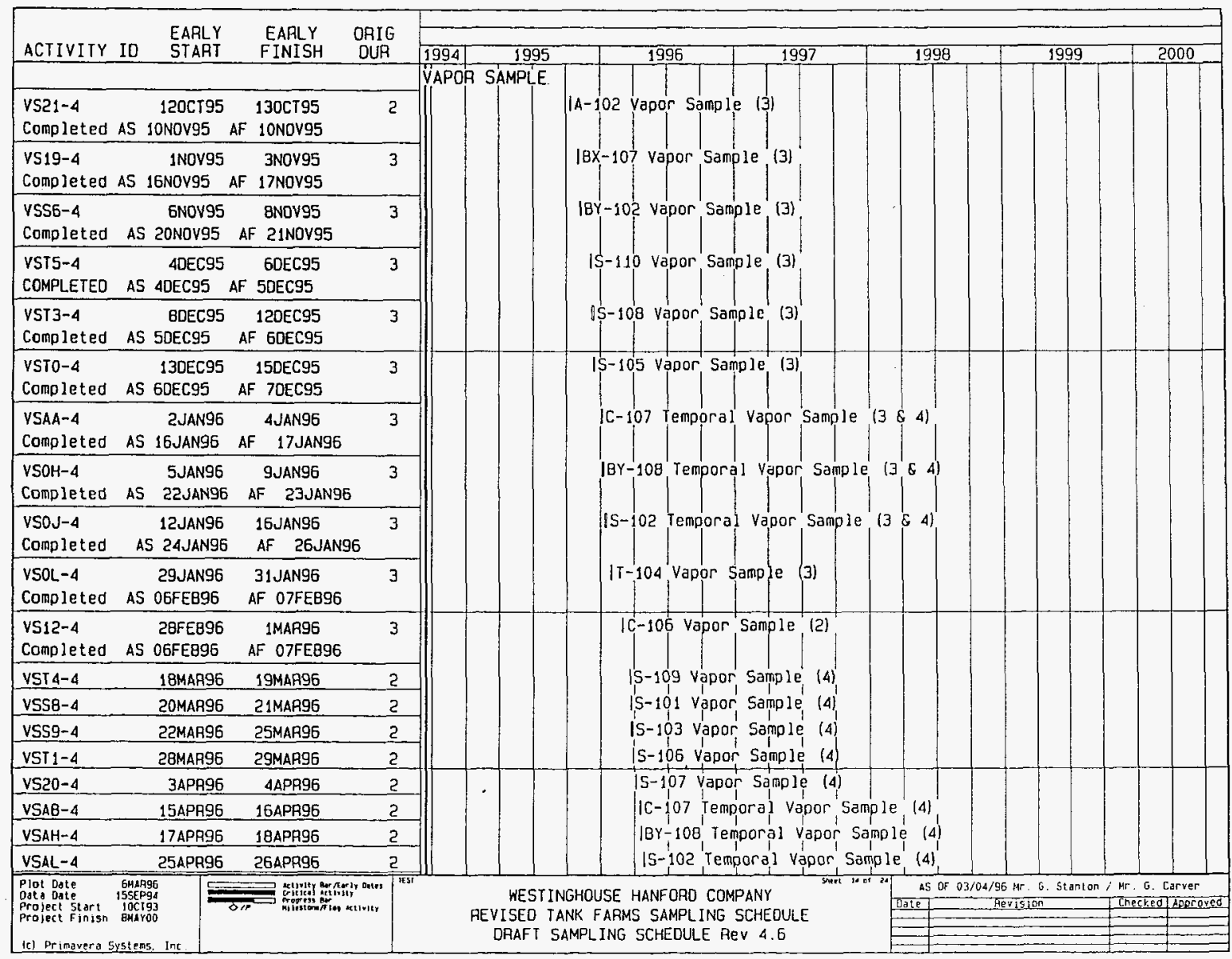


WHC-SD-WM-PLN-101, REV 2 APPENDIX E

Sampling Schedule: Subject to Change

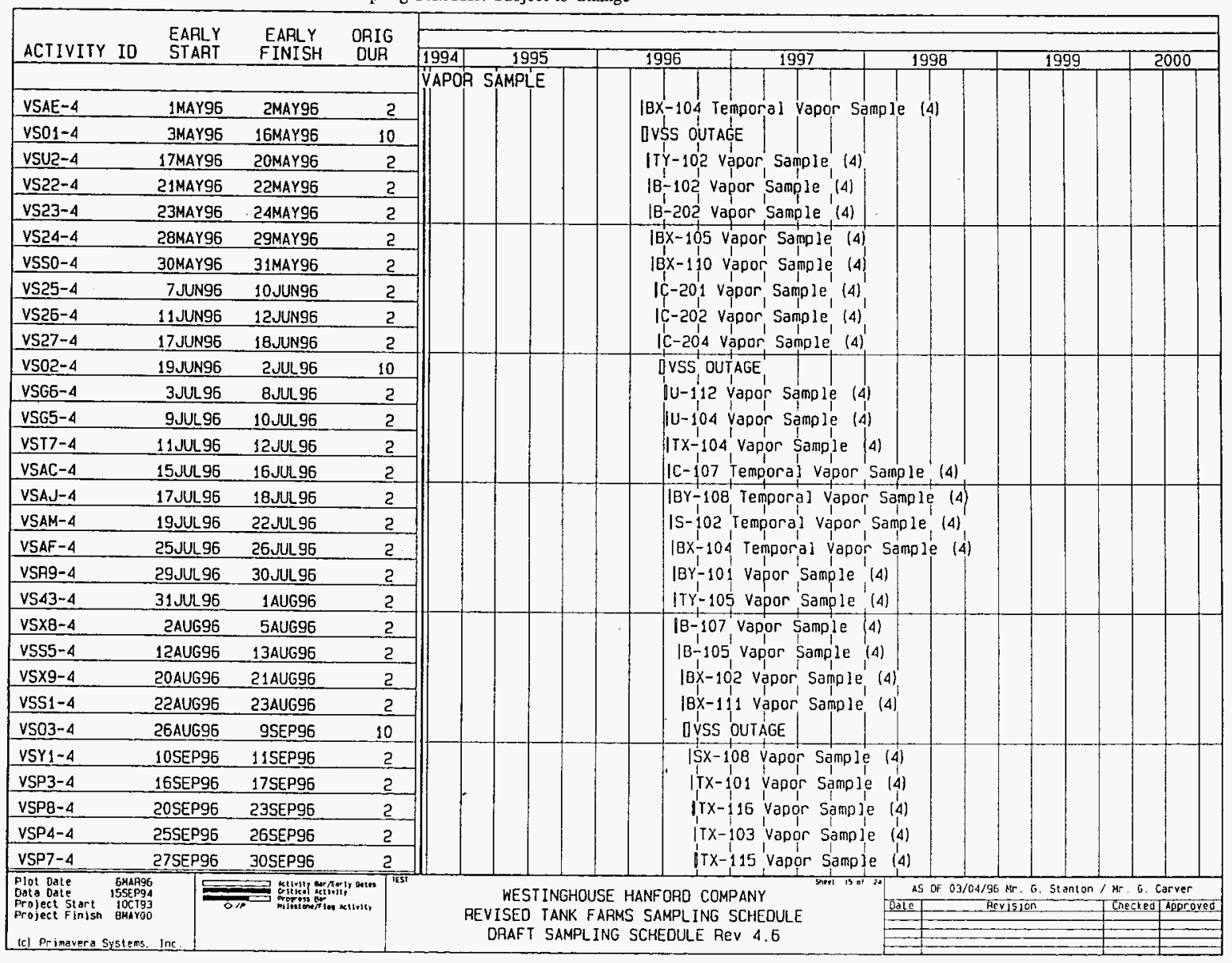


WHC-SD-WM-PLN-101, REV 2 APPENDIX E

Sampling Schedule: Subject to Change

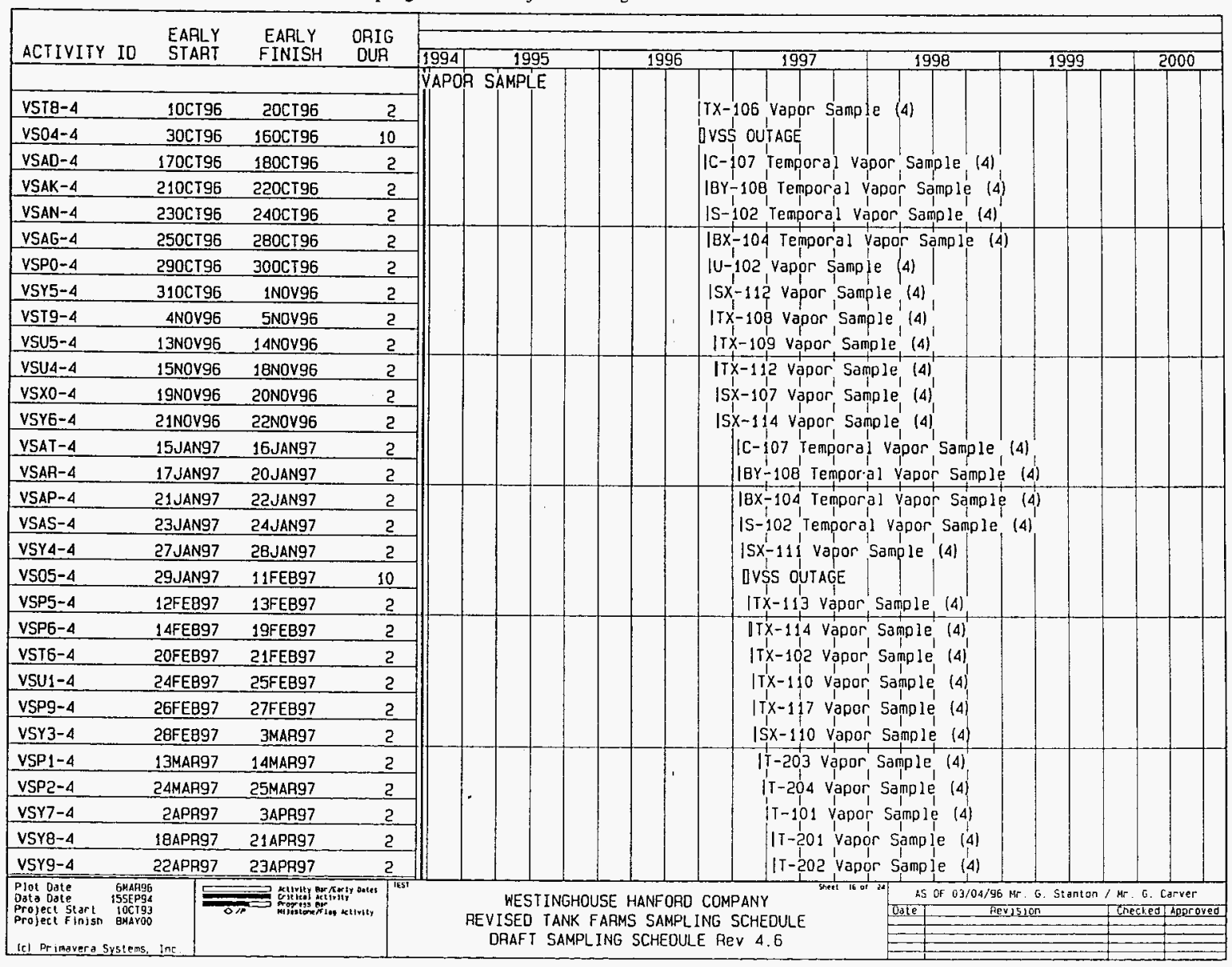


WHC-SD-WM-PLN-101, REV 2 APPENDIX E

Sampling Schedule: Subject to Change

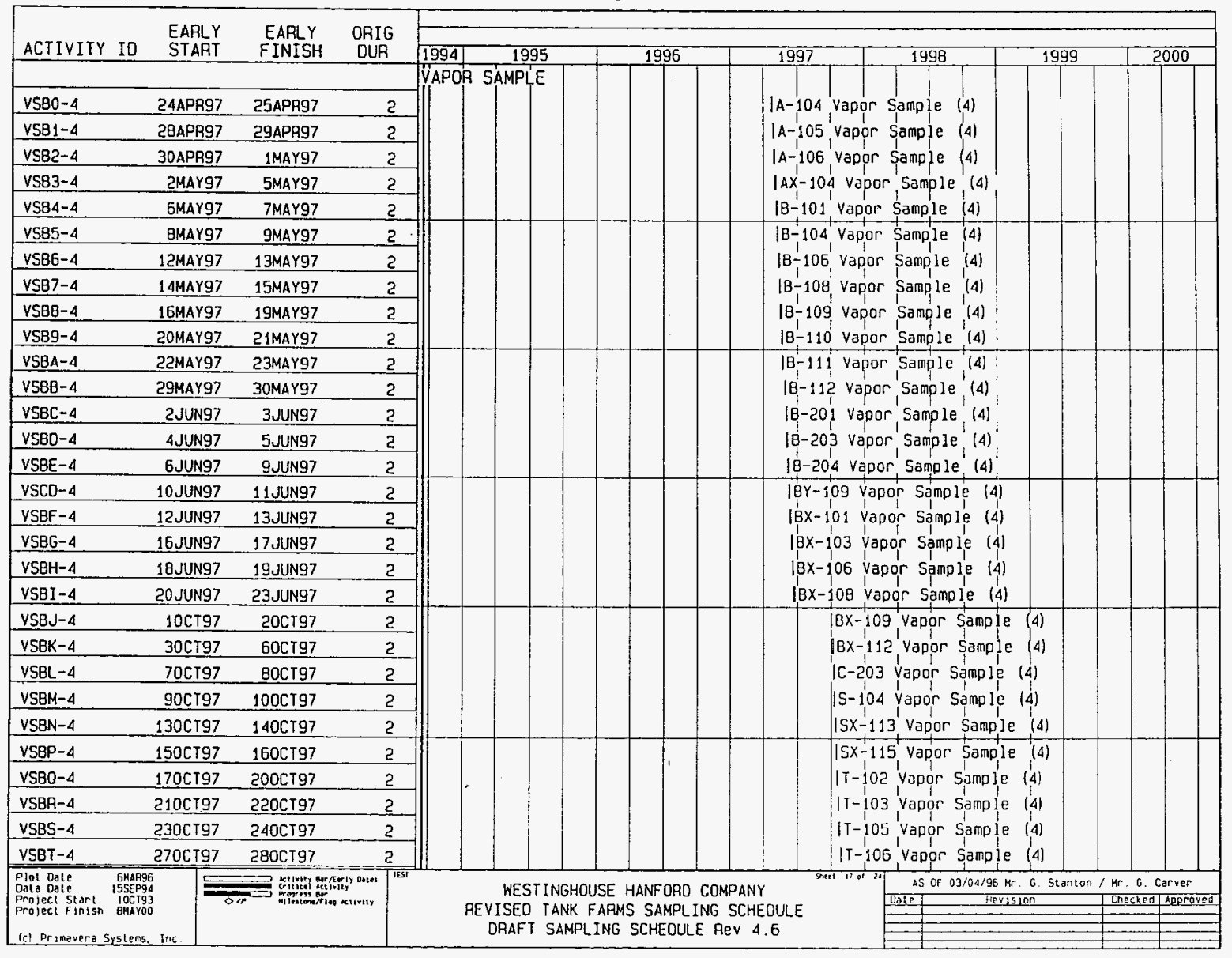




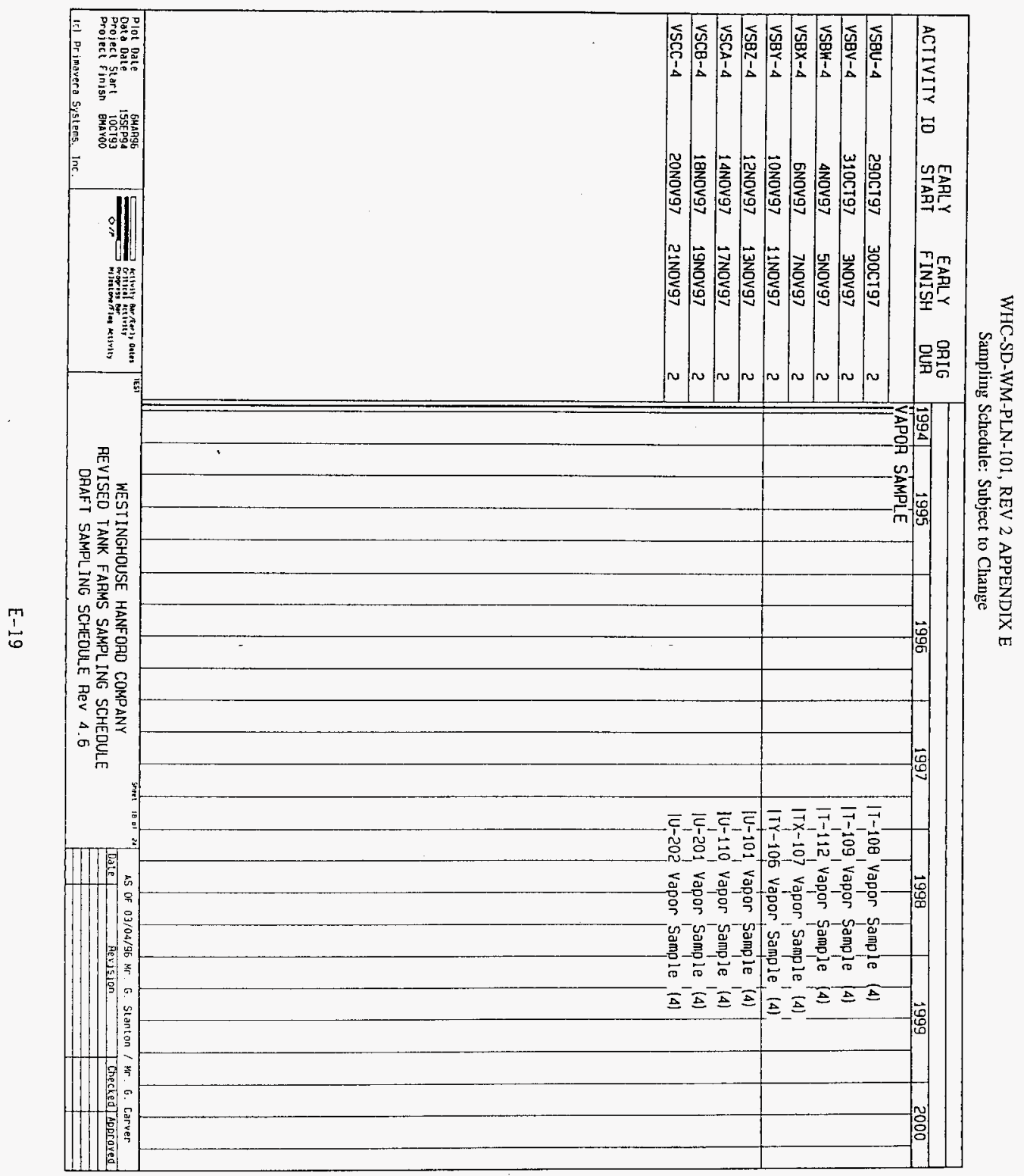


WHC-SD-WM-PLN-101, REV 2 APPENDIX E

Sampling Schedule: Subject to Change

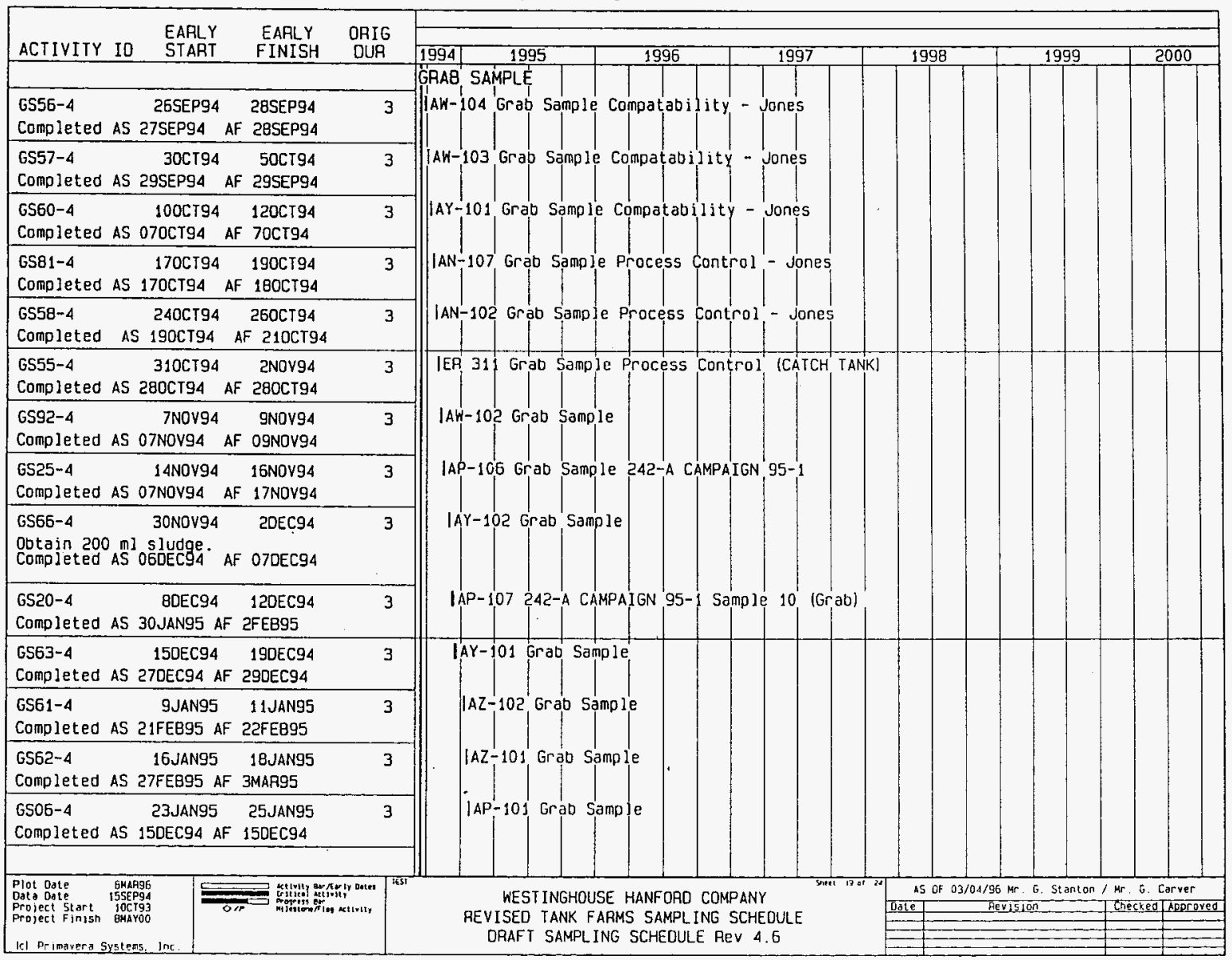




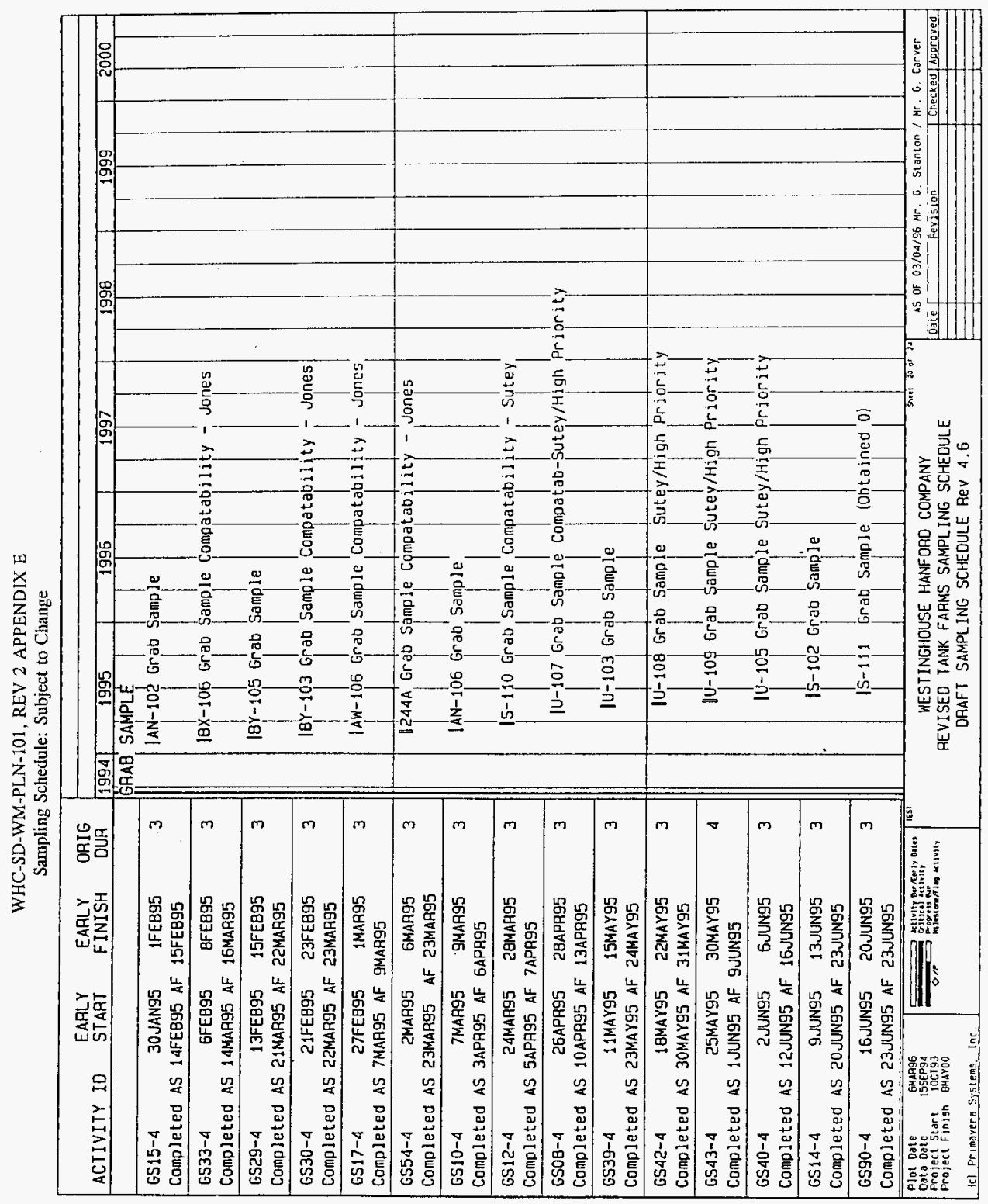


WHC-SD-WM-PLN-101, REV 2 APPENDIX E

Sampling Schedule: Subject to Change

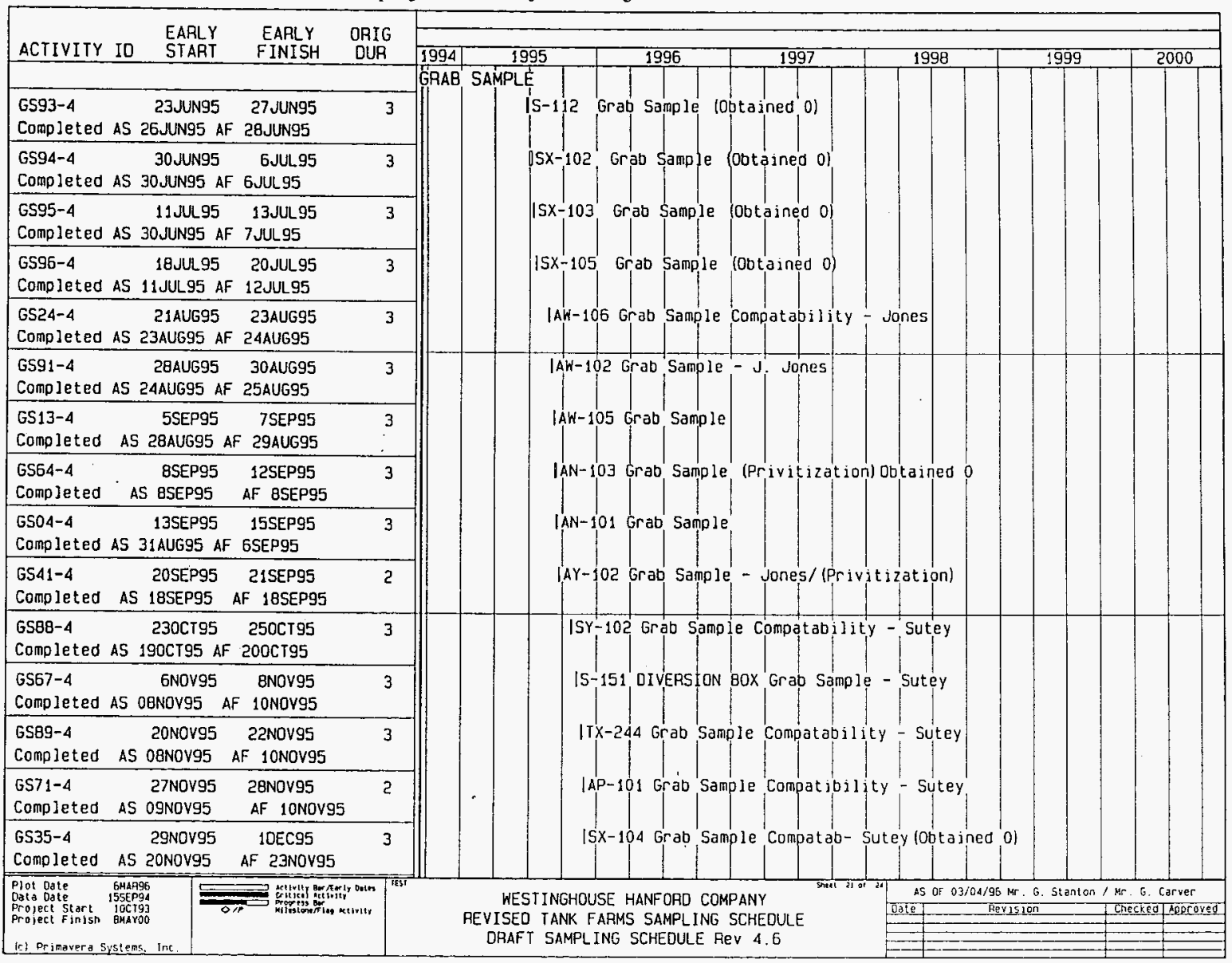


WHC-SD-WM-PLN-101, REV 2 APPENDIX E

Sampling Schedule: Subject to Change

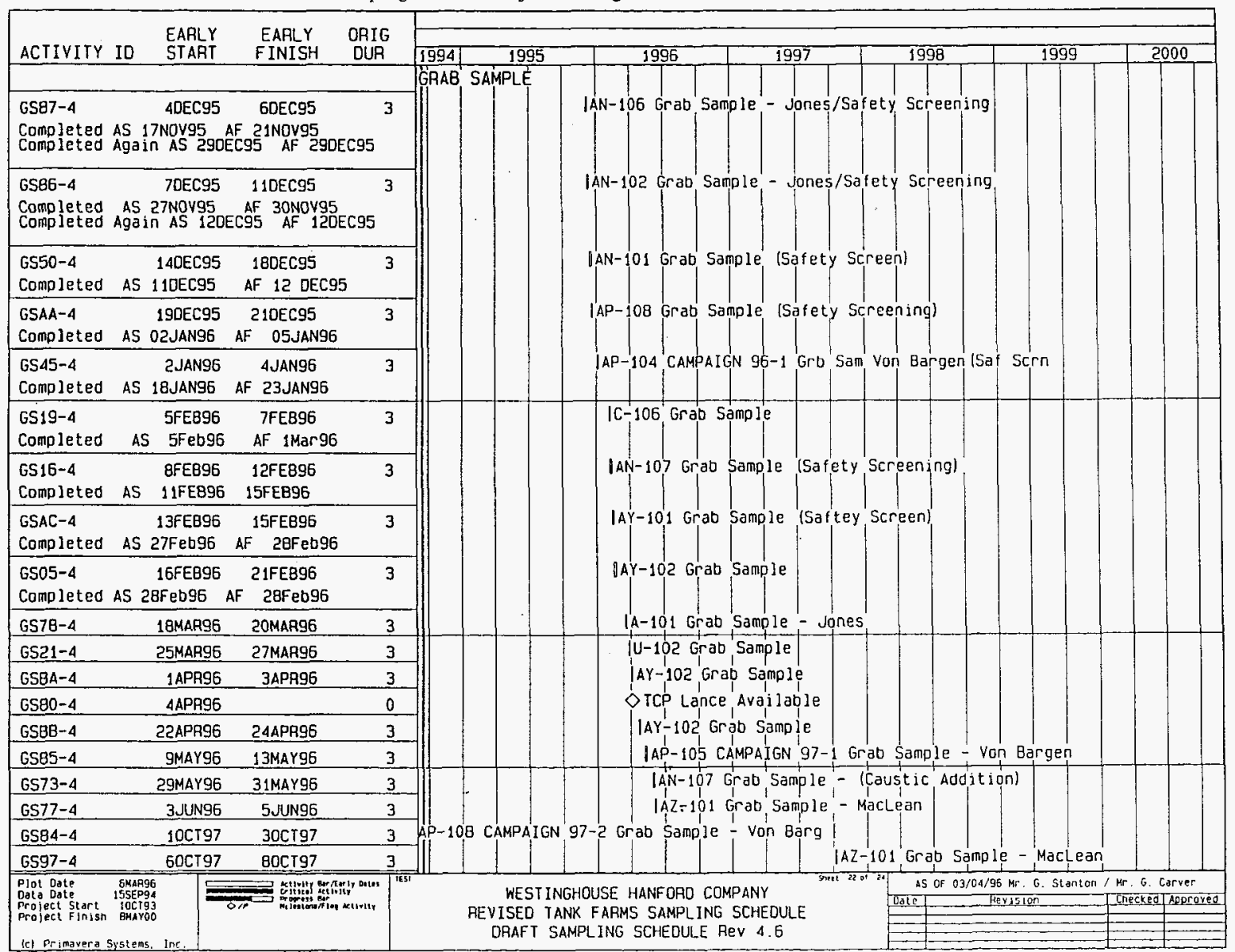


WHC-SD-WM-PLN-101, REV 2 APPENDIX E

Sampling Schedule: Subject to Change

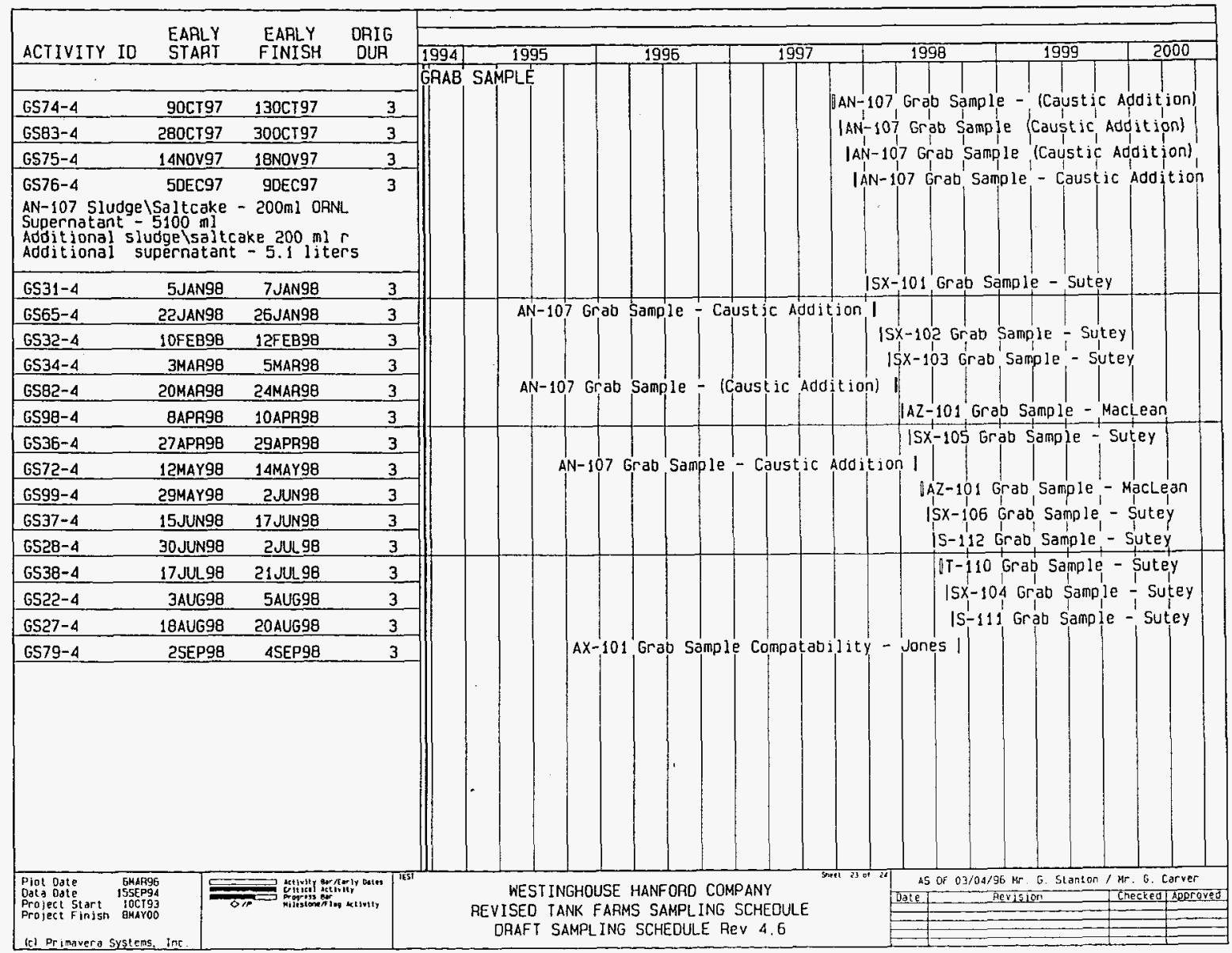




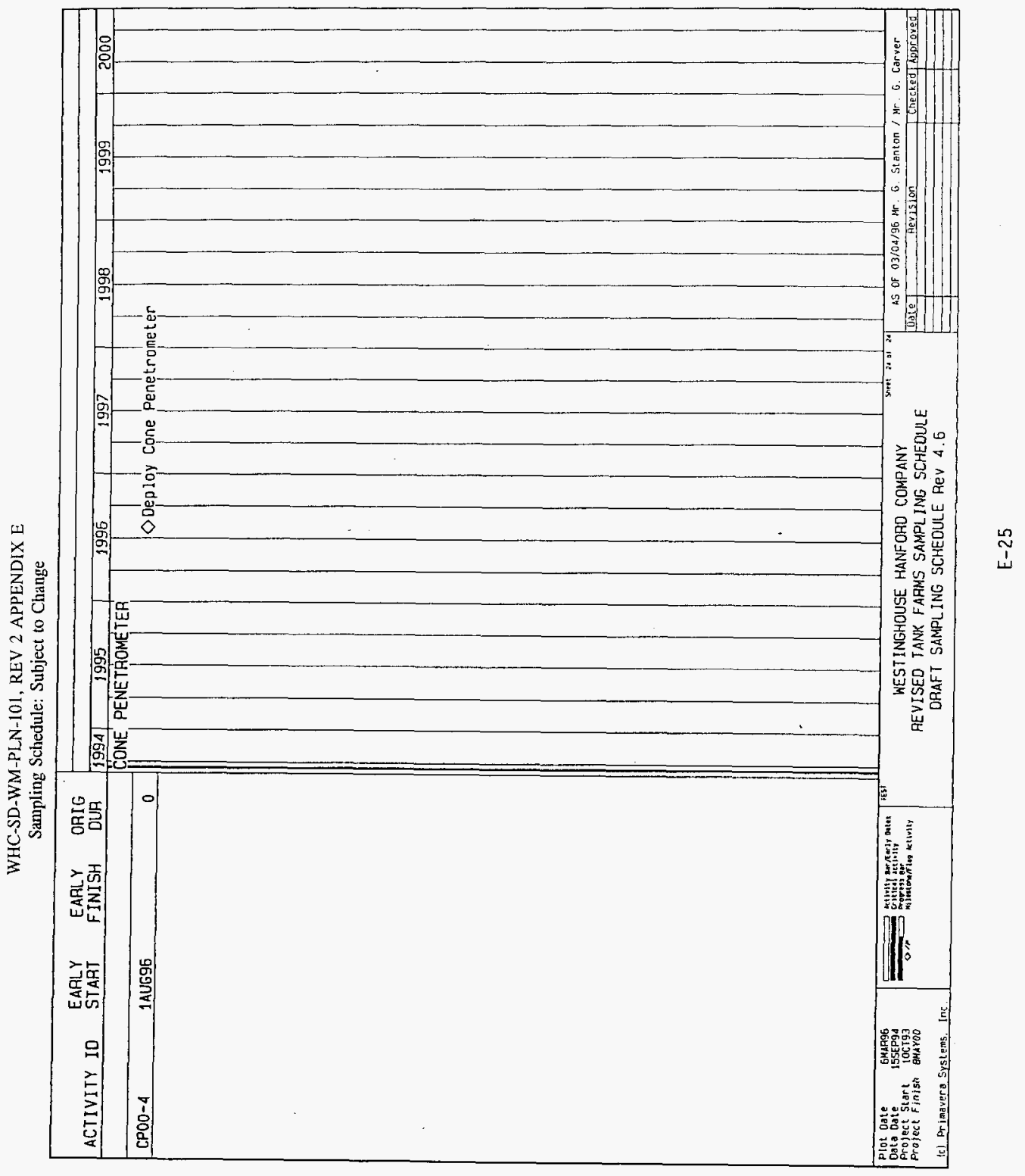




\section{DISTRIBUTION SHEET}

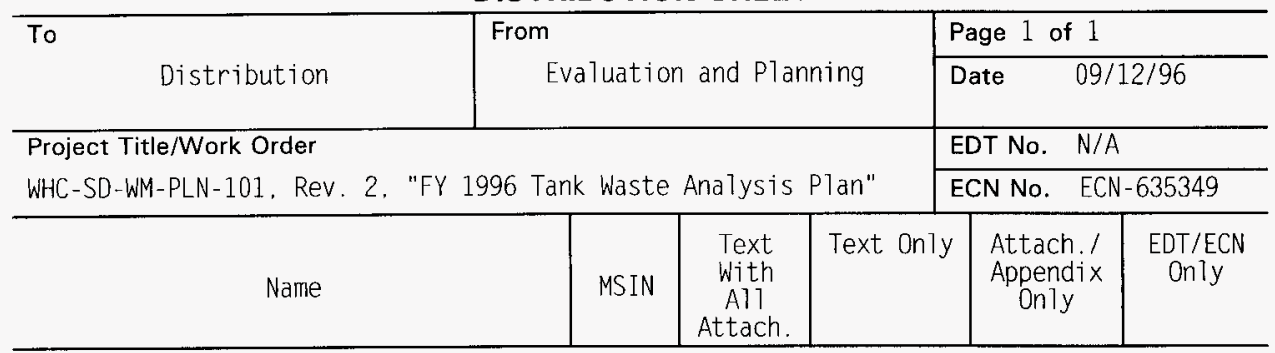

ONSITE

U. S. Department of Energy -

Richland Field office

W. Liou

$57-54 \quad x$

N. W. Willis

$57-54 \quad x$

Westinghouse Hanford Company

C. S. Homi

T. J. Kelley

Central Files

T.C.R.C.

$\begin{array}{ll}\text { R2 }-12 & X \\ \text { S7 }-21 & X \\ \text { A3 }-88 & X \\ \text { R2 }-12 & X\end{array}$

\section{OFFSITE}

U. S. Department of Energy - Headquarters

Office of Environmental Restoration and

Waste Management EM-563

12800 Middlebrook Road

Germantown. MD 20874

J. A. Poppiti 